\title{
Mitigating Negative Unintended Impacts on Biodiversity in the Natura 2000 Vouga Estuary (Ria de Aveiro, Portugal)
}

\author{
Ana I. Lillebø, Heliana Teixeira, Javier Martínez-López, \\ Ana Genua-Olmedo, Asya Marhubi, Gonzalo Delacámara, \\ Verena Mattheiß, Pierre Strosser, Timothy G. O'Higgins, \\ and António A. J. Nogueira
}

\begin{abstract}
This chapter presents the co-development of the Ecosystem-Based Management (EBM) planning process in the Vouga estuary for the mitigation of unintended impacts on biodiversity resulting from the 2019/2020 management plan. This estuary, part of Ria de Aveiro coastal lagoon located on the north-west coast of Portugal $\left(40^{\circ} 38^{\prime} \mathrm{N}, 08^{\circ} 45^{\prime} \mathrm{W}\right)$, connects the Vouga river catchment area to the Atlantic Ocean. Ria de Aveiro, part of the Natura 2000 network, is characterised by high biodiversity and a wide range of ecosystem services. However, it is also a vulnerable territory that requires a management plan in practice for environmental protection, targeting threatened species and habitats, but also to enable socioeconomic welfare. Framed by EBM principles, the stepwise planning approach aimed at identifying the governance boundaries and institutions, the policy objectives, synergies, and gaps relevant to managing biodiversity, and to promote participatory actions with local stakeholders and policy-makers to understand their objectives. These three first steps enabled us to understand the social-ecological system and to co-develop relevant EBM solutions. In the final step, the proposed
\end{abstract}

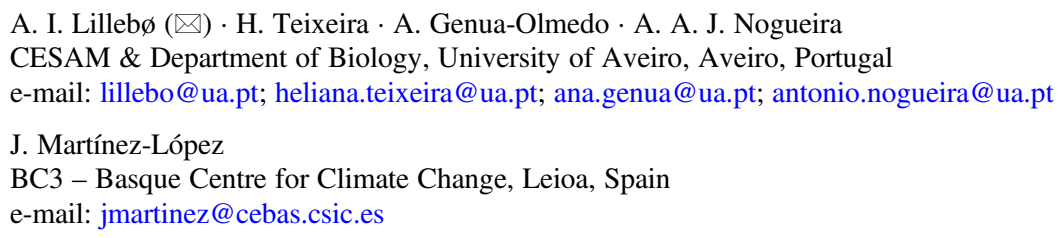


EBM solutions were evaluated for effectiveness, efficiency, equity and fairness, and then compared to the present condition. The co-developed solutions target science, policy and stakeholders interfaces. Namely, scientific knowledge applied to restore saltmarshes and seagrasses, policy objectives harmonising monitoring across EU Directives and integrate territorial management instruments, and management process involving stakeholders throughout.

Lessons Learned The co-created EBM plan for the Vouga estuary Natura 2000 site is foreseen to support the further development of the Vouga Estuary Management Plan. To this end, it is also foreseen to support actions for a more comprehensive understanding of the social-economic implications of the provided ecosystem services in line with the Centro Portugal region strategy for smart specialisation (Portugal RIS3 Centro).

These are:

- Continue to increase stakeholder participation: stakeholders want to contribute to management and actively participate in the co-creation of adaptive management solutions;

- Integrate and coordinate policies: proceed with the development of the Vouga estuary management plan considering connectivity across water domains, landowners and users;

- Promote adaptive management and acknowledge unintended impacts: harmonise existing mandatory monitoring programmes to support regular evaluation and enable adaptive management involving stakeholders to respond to future management needs and challenges.

\section{Needs to Advance EBM}

- At the scale of Natura 2000 Vouga estuary, EBM plans should be co-created with input from local stakeholders and policy-makers. To protect biodiversity, managers should consider climate change projections and acknowledge uncertainty. For the successful implementation of the identified water and nature policies in places like the Vouga estuary, any actions need to ensure involvement of users and landowners.

- At a global scale, and particularly at European Union scale, it has been acknowledged that biodiversity protection is still deficient and that, at current trends, the EU Strategy for 2020 will fail to achieve its goal of halting loss of biodiversity. To this end, EBM, that encompasses any management or policy options intended to restore, enhance or protect the resilience of the ecosystem, appears as a valuable approach in support of EU Strategy beyond 2020. 


\section{Introduction}

The United Nations (UN) 2011 declaration of the 2011-2020 Decade on Biodiversity brought to the forefront news the urgent need to halt the loss of biodiversity as well as its overall vision for 2050 of "living in harmony with nature". It also made clear the fact that ecosystem functioning and the provision of ecosystem services essential for human well-being are supported by biological diversity. Within the UN Environment Programme, the Convention on Biological Diversity (CBD) developed The Strategic Plan for Biodiversity with a shared vision, mission, and set of strategic goals: the Aichi Biodiversity Targets. ${ }^{1}$

To this end, the European Union (EU) Biodiversity Strategy to 2020 aims at ensuring the existence and conservation of biodiversity and ecosystem services and at halting the loss of global biodiversity (European Commission 2011). Its main objective is to fulfil the implementation of nature protection legislation, with special emphasis in Natura 2000 sites with high biodiversity value. This strategy includes six targets focused on: better protection and restoration of ecosystems and their associated services; establishment of green infrastructure; development of sustainable agriculture and fisheries; control of invasive alien species; and an EU contribution to stop global biodiversity loss.

Action 5 is based on improving knowledge on ecosystem services. The use of maps helps to achieve this action by characterizing the spatial heterogeneity of ecosystems and services they supply, and the associated pressures and impacts. They also help to translate scientific evidence into information that is understandable for policy and decision making (Maes et al. 2016). Thus, mainstreaming values of biodiversity and ecosystem services into decision-making is expected to help increase awareness about the implications of further degradation and loss of natural ecosystems on human well-being (Teixeira et al. 2018, 2019).

An Ecosystem-Based Management (EBM) of aquatic ecosystems is more likely to support a timely achievement of the EU 2020 Biodiversity Strategy targets than isolated sectorial management initiatives (Piet et al. 2017; Martínez-López et al. 2019a). Such an integrative approach to ecological, social and governance principles sets an adequate context to apply socio-ecological concepts such as ecosystem services in practical management initiatives (Lillebø et al. 2019; Martínez-López et al. 2019b). The EBM planning process involves the coordination of policies, institutions and practices (Drakou et al. 2017; Piet et al. 2017; Rouillard et al. 2018), representing a holistic approach that aims to balance multiple interrelated dimensions of ecological integrity and human well-being (Gómez et al. 2016, 2017; Langhans et al. 2019).

Following Rouillard et al. (2018), the proposed approach aiming at mitigating negative unintended impacts on biodiversity in the Natura 2000 Vouga estuary

\footnotetext{
${ }^{1}$ Aichi Biodiversity Targets: https://www.cbd.int/doc/strategic-plan/2011-2020/Aichi-Targets-EN. pdf.
} 
considers the following principles (Curtin and Parker 2014; Gómez et al. 2016, 2017; Martin et al. 2018):

- EBM considers ecological integrity, biodiversity, resilience and ecosystem services;

- EBM is carried out at appropriate spatial scales;

- EBM develops and uses multi-disciplinary knowledge;

- EBM builds on social-ecological interactions, stakeholder participation and transparency;

- EBM supports policy coordination;

- EBM incorporates adaptive management.

\subsection{Study Site}

Ria de Aveiro is a shallow coastal lagoon located on the north-west coast of Portugal $\left(40^{\circ} 38^{\prime} \mathrm{N}, 08^{\circ} 45^{\prime} \mathrm{W}\right)$. The adjacent coast experiences strong seasonal upwelling, the designated North Atlantic Upwelling that supports high levels of productivity especially in summer (Lopes et al. 2014). The lagoon establishes the aquatic continuum between the upstream catchment area $\left(3500 \mathrm{~km}^{2}\right)$ of the Vouga river that contributes with circa $80 \%$ of the freshwater inflow, and the Atlantic Ocean through a single connection (1.3 km length, $350 \mathrm{~m}$ wide and $20 \mathrm{~m}$ depth) (e.g., Lillebø et al. (eds) 2015; Stefanova et al. 2015; Sousa et al. 2016; Lopes et al. 2017). These hydrographical settings determine that the Vouga river estuary is located within the boundaries of Ria de Aveiro coastal lagoon.

Due to its valuable natural capital, listed under both the Birds Directive and the Habitats Directive, Ria de Aveiro is a classified site under the Natura 2000 network, entailing a Special Protection Area (SPA) that includes extensive saltmarsh habitats and the adjacent marine area. Since 2011, the lagoon is also an International LongTerm Ecosystem Research (ILTER) site. Within the lagoon watershed Aveiro city represents the major urban settlement with circa 60,000 inhabitants. Like other social-ecological systems, the Vouga estuary is subject to co-competing land and water uses (Lilleb $\varnothing$ et al. (eds) 2015). Previous trans-disciplinary studies acknowledged the importance of the Vouga estuary's geographic location combined with its natural capital, which has enabled the development of a wide variety of economic, cultural and recreational activities (Lillebø et al. (eds) 2015; Dolbeth et al. 2016; Lillebø et al. 2016; Sousa 2017; O'Higgins et al. 2019). However, this area often requires human intervention for protection, or to enable economic activities, due to anthropogenic pressures impacting the hydro-morphological conditions of the lagoon, the Vouga estuary, and the adjacent Baixo Vouga Lagunar freshwater section of the Vouga river, and natural pressures like ocean storm surges, coastal erosion, and torrential rain and flood events (Pereira and Coelho 2013; Lillebø et al. (eds) 2015; Dolbeth et al. 2016; Lopes et al. 2017; Luís et al. 2018). 


\subsection{Biodiversity Challenge in the Natura 2000 Vouga Estuary}

Two management interventions, occurring during 2019/2020, will likely have negative unintended impacts on biodiversity (Lillebø et al. 2019; Martínez-López et al. 2019b):

- Dredging programme to enable hydrodynamic equilibrium and navigability in Ria de Aveiro coastal lagoon (APA 2018);

- Extension of a flood bank to disable surface saltwater intrusion into Baixo Vouga Lagunar agricultural areas, named 'Sistema de Defesa Primária do Baixo Vouga Lagunar' (DGADR 2017).

The dredging programme's ultimate goal is to improve lagoon navigability and is expected to allocate part of its dredged sediments to reinforce the banks at lower elevation zones, threatened by surface saltwater intrusion from inundation, for the protection of infrastructures and goods. Additional dredged sand will be used for beach replenishment. The extension of the flood bank is expected to improve accessibilities, foster agricultural and livestock activities, and protect wildlife and other economic activities, namely ecotourism with bird watching tours, angling, and recreational activities at the upstream area of the flood bank. These two management options will cause negative, unintended impacts on biodiversity, including changes of the system's eco-hydrodynamics, including water current velocity, turbidity, and tidal prism that will impact seagrasses and saltmarshes (Lillebø et al. (eds) 2015, 2019; Dolbeth et al. 2016). Additionally, downstream saltmarshes will be subdued to "coastal squeeze" as the combined effect of the physical flood bank barrier with the increase tidal prism will result in longer submersion periods that saltmarsh species are not adapted to (Martínez-López et al. 2019b).

The goals of our EBM approach are to:

- Contribute to operationalising an EBM planning process in response to foreseen unintended impacts resulting from the present management options;

- Mitigate unintended impacts from a major dredging programme targeting the hydrodynamic equilibrium (APA 2018);

- Mitigate unintended impacts from the extension of a flood bank targeting surface saltwater intrusion into agricultural areas (DGADR 2017);

- Make use of the best available information in a trans-disciplinary context.

To reach these goals, the overarching policies, programmes, key governance institutions, and objectives relevant to managing biodiversity were identified. Stakeholders were engaged throughout the process in order to co-define the baseline, co-develop management scenarios, and co-create the EBM plan. 


\section{The EBM Planning Approach}

To address the governance challenges in the frame of the Vouga estuary, the EBM planning approach followed a stepwise procedure.

\subsection{Step One: Setting the Governance Boundary}

In order to be policy relevant the governance boundaries for this EBM approach were set at $500 \mathrm{~m}$ from the aquatic realm boundary (Fig. 1) following the Vouga Estuary Management Plan under development by the Portuguese Environmental Agency. ${ }^{2}$ This Plan links public administration and private sectors, and provides the basis to effectively manage Ria de Aveiro's natural capital, ecosystem services and associated socio-economic activities. It encompasses an integrated land-use management plan with appropriate measures to protect all wetlands habitats, e.g., transitional waters, mud and sand flats, seagrasses and salt marshes, as well social, economic and cultural development. As shown by O'Higgins et al. (2019), the $500 \mathrm{~m}$ boundary is well aligned with ecosystem service production and consumption boundaries of this resource system. In this way, the Vouga Estuary Management Plan policy boundary overlaps with the production and consumption of relevant ecosystem services. Furthermore, the Plan foresees the articulation of territorial management instruments, plans and programmes at different scales, from local to regional (Centro Portugal region) and national, covering appropriate spatial scales for the EBM approach.

\subsection{Step Two: Identify Policy Objectives, Synergies, and Gaps}

The most relevant national policy plans and programmes (and institutions responsible for implementation of the policy instruments), objectives for the planning process of EBM responses, as well as linkages to EU Policies, are presented in Table 1. These initiatives cover aspects from nature conservation, to water quality and management, to climate change adaptation and tourism. The later are key drivers for sustainable economic growth of the Centro Portugal region (Dolbeth et al. 2016). At local/regional scales, it is also important to consider sectoral plans and programmes that integrate operations, enable collaborative work among institutions, and promote articulation of environmental, economic and social factors. The most relevant national and regional institutions to be considered in the planning process of EBM responses are presented in Table 2.

\footnotetext{
${ }^{2}$ Agência Portuguesa do Ambiente, I.P.—APA, https://www.apambiente.pt/.
} 

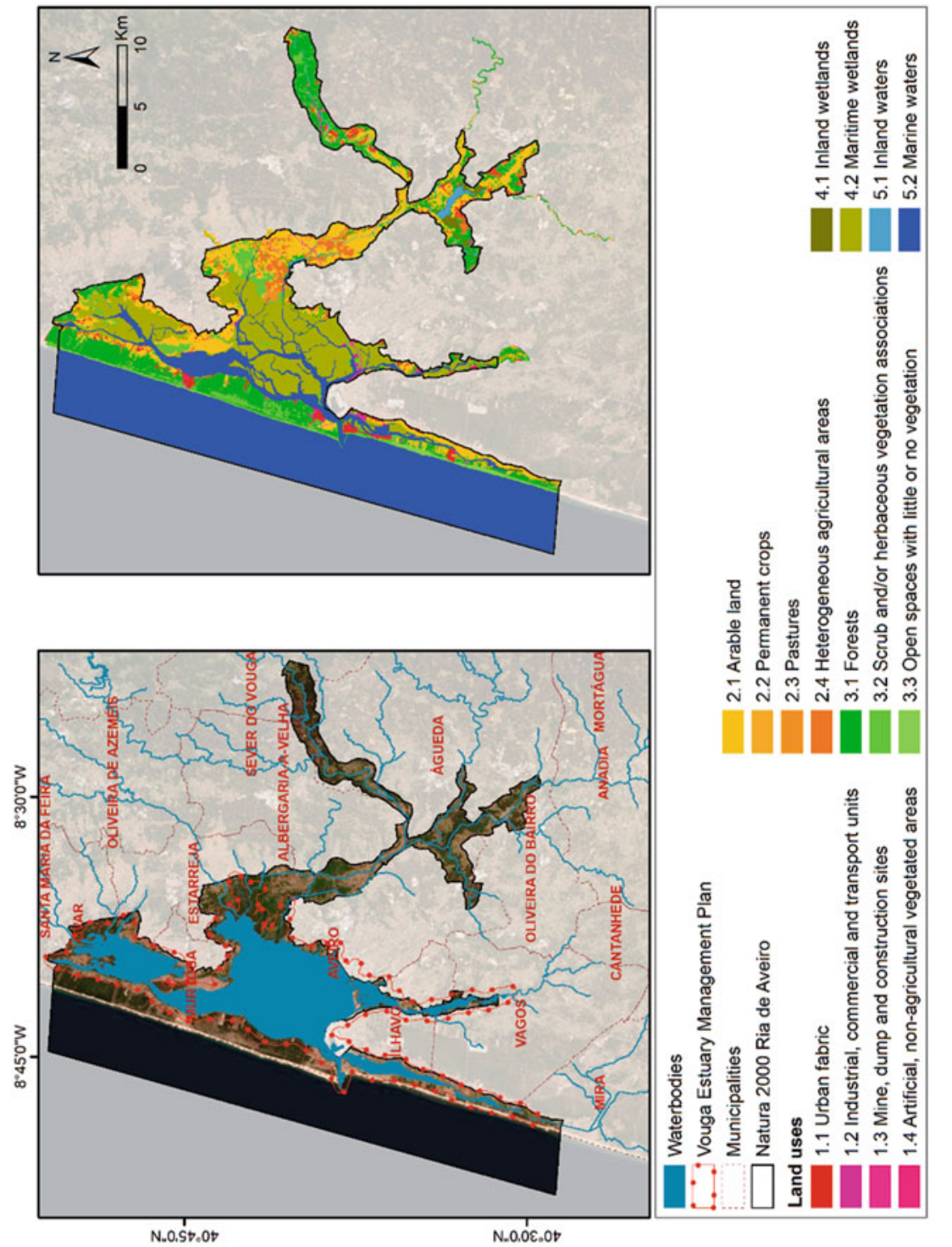

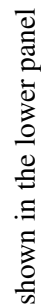

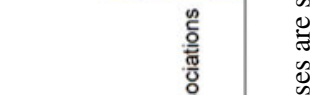

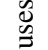


Table 1 Identification of national relevant policy plans and programmes, and objectives for the EBM planning process at Ria de Aveiro: (a) link to EU policies and (b) link to regional/local policies

\begin{tabular}{|c|c|c|}
\hline Policy plans and programmes & Objectives & (a) Link to EU policies \\
\hline $\begin{array}{l}\text { Sectoral Plan for Natura } 2000 \\
\text { Network (PSRN2000) } \\
\text { Institute for Nature Conserva- } \\
\text { tion and Forests (ICNF) }\end{array}$ & $\begin{array}{l}\text { Territorial management tool for } \\
\text { implementation of the national } \\
\text { policy for conservation of bio- } \\
\text { logical diversity, aiming at } \\
\text { safeguarding and enhancement } \\
\text { of sites and SPAs of the conti- } \\
\text { nental territory, as well as } \\
\text { maintenance of species and } \\
\text { habitats in a favourable con- } \\
\text { servation status in these areas }\end{array}$ & $\begin{array}{l}\text { Birds Directive (2009/147/ } \\
\text { EC); Habitats Directive } \\
\text { (92/43/EEC) }\end{array}$ \\
\hline $\begin{array}{l}\text { National Water Plan (Decreto- } \\
\text { Lei no. 76/2016) } \\
\text { Inter-ministerial Commission } \\
\text { for Water management: } \\
\text { APA/ARHC; ICNF; Regional } \\
\text { Directorate for Agriculture and } \\
\text { Fisheries (DRAP); } \\
\text { Directorate-General for Marine } \\
\text { Resources (DGRM) }\end{array}$ & $\begin{array}{l}\text { Governmental cross-sectoral } \\
\text { management for the next } \\
10 \text { years: Increase water pro- } \\
\text { ductivity and promoting ratio- } \\
\text { nal use, with maximum respect } \\
\text { for territorial integrity of the } \\
\text { river basins; Protection, con- } \\
\text { servation and rehabilitation of } \\
\text { water resources and associated } \\
\text { ecosystems; Meeting needs of } \\
\text { the population and country's } \\
\text { economic and social develop- } \\
\text { ment; Respect for relevant } \\
\text { national and Community legis- } \\
\text { lation and satisfaction of inter- } \\
\text { national commitments } \\
\text { assumed by the Portuguese } \\
\text { State; Access to information } \\
\text { and participation of citizens in } \\
\text { management of water } \\
\text { resources }\end{array}$ & $\begin{array}{l}\text { Water Frame Directive } \\
\text { (WFD) (2000/60/EC) } \\
\text { Floods Directive (2007/60/ } \\
\text { EC) } \\
\text { Marine Strategy Framework } \\
\text { Directive }(2008 / 56 / E C)\end{array}$ \\
\hline $\begin{array}{l}\text { River Basin Management Plan } \\
(P G B H-R H 4) \\
\text { Portuguese Environment } \\
\text { Agency (APA/ARHC) }\end{array}$ & $\begin{array}{l}\text { Outlines water planning for the } \\
\text { tri-basin region of Vouga, } \\
\text { Mondego and Lis, in accor- } \\
\text { dance with WFD }\end{array}$ & WFD (2000/60/EC) \\
\hline $\begin{array}{l}\text { National Strategic Plan for } \\
\text { climate change adaptation } \\
\text { (ENAAC) } \\
\text { Ministry of Environment }\end{array}$ & $\begin{array}{l}\text { Establishes the need for adap- } \\
\text { tation. Contains the National } \\
\text { adaptation strategy, and asso- } \\
\text { ciated action plan, including } \\
\text { reducing vulnerability and } \\
\text { increasing response capacity. }\end{array}$ & $\begin{array}{l}\text { EU Strategy on Adaptation to } \\
\text { Climate Change (COM } \\
\text { (2013) } 216\end{array}$ \\
\hline $\begin{array}{l}\text { National Strategic Plan for } \\
\text { Tourism (PENT) } \\
\text { Ministry of Economy and } \\
\text { Innovation }\end{array}$ & $\begin{array}{l}\text { Serves as basis for implemen- } \\
\text { tation of a series of initiatives } \\
\text { aimed at fostering sustained } \\
\text { growth of national tourism } \\
\text { over the coming } 10 \text { years, and } \\
\text { guiding activities of Portugal }\end{array}$ & $\begin{array}{l}\text { EU strategy for a smart, sus- } \\
\text { tainable and inclusive growth } \\
\text { (COM (2014) } 85 \text { final, 2014/ } \\
\text { 0044) }\end{array}$ \\
\hline
\end{tabular}


Table 1 (continued)

\begin{tabular}{l|l|l}
\hline Policy plans and programmes & Objectives & (a) Link to EU policies \\
\hline & $\begin{array}{l}\text { National Tourism Authority, as } \\
\text { the key public body for the } \\
\text { sector. }\end{array}$ & \\
\hline $\begin{array}{l}\text { Polis Litoral Ria de Aveiro } \\
\text { APA/ARHC; ICNF }\end{array}$ & $\begin{array}{l}\text { Integrated Operations of Reha- } \\
\text { bilitation and Recovery of } \\
\text { Coastal Areas. Strong collabo- } \\
\text { rative work between central } \\
\text { administration and the Ria de } \\
\text { the Aveiro Region Inter- } \\
\text { municipal Community (CIRA) }\end{array}$ & $\begin{array}{l}\text { Address the regional policy } \\
\text { instruments } \\
\text { Contribute to the Vouga } \\
\text { estuary management plan } \\
\text { Contribute to the Regional } \\
\text { strategy for smart specializa- } \\
\text { tion (RIS3 Centro) }\end{array}$ \\
\cline { 1 - 2 } $\begin{array}{l}\text { Coastal Zone Management } \\
\text { Programme Ovar-Marinha } \\
\text { Grande (POC-OMG) }\end{array}$ & $\begin{array}{l}\text { Reconcile the various conflicts } \\
\text { of uses of the coastal zone, } \\
\text { promoting articulation of } \\
\text { APA/ARHC }\end{array}$ & \\
\cline { 1 - 2 } $\begin{array}{l}\text { River Basin Managenental, economic and } \\
\text { social factors related to coastal } \\
\text { management. }\end{array}$ & \\
$\begin{array}{l}\text { Portuguese Environment } \\
\text { Agency (APA/ARHC) }\end{array}$ & $\begin{array}{l}\text { Outlines water planning for } \\
\text { the tri-basin region of Vouga, } \\
\text { Mondego and Lis, in accor- } \\
\text { dance with WFD }\end{array}$ & \\
\hline
\end{tabular}

Source: Lillebø et al. (2019)

Each policy main objective (Table 1) identifies regional policy instruments contributing to the Vouga Estuary Management Plan, which aims at contributing to the Centro Portugal region strategy for smart specialisation (Portugal RIS3 Centro). Within this strategy, sea-related economic activities were selected as a strategic priority together with agriculture, forestry, tourism, information and communication technologies, materials, biotechnology, and health and wellness. The boundary for the Vouga Estuary Management Plan is presented and discussed in Fidélis and Carvalho (2015), and is considered as management boundary in O'Higgins et al. (2019) and in the proposed EBM approach (see Sect. 2.1). The Vouga Estuary Management Plan requires coordination with:

- Sectoral Plan for Natura 2000 Network (Institute for Nature Conservation and Forests; ICNF, I.P.), the territorial management tool for implementation of the national policy for the conservation of biological diversity;

- National Strategic Plan for climate change adaptation, following climate change projections, and containing the National adaptation strategy and associated action plan relevant in Centro Portugal coastal area.

The proposed EBM approach requires monitoring the policy impact of unintended pressures resulting from present management options. Although most of the information is reported in the frame of these EU water-related and Nature Directives, data sets are not harmonised. Therefore, the main gap identified concerns 
Table 2 Identification of main institutions and policy domains for the EBM planning process

\begin{tabular}{|c|c|c|}
\hline Institution & Policy domain & Additional information \\
\hline $\begin{array}{l}\text { Portuguese Environmental } \\
\text { Agency (APA, I.P.) through } \\
\text { the Regional Hydrographic } \\
\text { Administrations (ARH } \\
\text { Centro) }\end{array}$ & $\begin{array}{l}\text { River Basin Management Plan } \\
\text { (WFD) and Flood Risk Man- } \\
\text { agement Plan (Floods Direc- } \\
\text { tive) for hydrographic Region } \\
4 \text { (RH4) that includes Vouga, } \\
\text { Mondego and Lis Rivers, and } \\
\text { the foreseen estuary land use } \\
\text { and management plans. }\end{array}$ & $\begin{array}{l}\text { APA/ARH Centro is respon- } \\
\text { sible for: water resources } \\
\text { management; spatial planning } \\
\text { of water resources, uses } \\
\text { (including the economic anal- } \\
\text { ysis) and demands, and law } \\
\text { enforcement; and for strategic } \\
\text { and integrated planning of the } \\
\text { coastal zone. }\end{array}$ \\
\hline $\begin{array}{l}\text { Institute for Nature Conserva- } \\
\text { tion and Forests (ICNF, I.P.) }\end{array}$ & $\begin{array}{l}\text { Sectoral Plan for Natura } 2000 \\
\text { Network (Habitats, Birds } \\
\text { Directives; Biodiversity } \\
\text { Strategy) }\end{array}$ & $\begin{array}{l}\text { ICNF, I.P. is the national } \\
\text { authority for nature conserva- } \\
\text { tion, biodiversity and forests; } \\
\text { articulates and promotes inte- } \\
\text { gration of forest policy and } \\
\text { conservation of nature and } \\
\text { biodiversity in policies to } \\
\text { combat desertification; to } \\
\text { mitigate climate change and } \\
\text { its effects; and to reduce } \\
\text { country's energy dependence. }\end{array}$ \\
\hline $\begin{array}{l}\text { Centro Region Department of } \\
\text { Agriculture and Fisheries } \\
\text { (DRAPC) }\end{array}$ & $\begin{array}{l}\text { Common Agricultural Policy } \\
\text { (CAP) and Common Fisheries } \\
\text { Policy (CFP) }\end{array}$ & $\begin{array}{l}\text { DRAPC is a service of the } \\
\text { Ministry of Agriculture, For- } \\
\text { estry and Rural Development, } \\
\text { whose mission is to partici- } \\
\text { pate in formulation and } \\
\text { implementation of policies in } \\
\text { agriculture, rural development } \\
\text { and fisheries, as well as col- } \\
\text { laborate in policies in areas of } \\
\text { forests, food security and } \\
\text { plant health, in liaison with } \\
\text { relevant central bodies and } \\
\text { services within the framework } \\
\text { of the efficiency of local } \\
\text { management of resources. }\end{array}$ \\
\hline $\begin{array}{l}\text { Directorate general for Natural } \\
\text { Resources, Safety and Mari- } \\
\text { time Services (DGRM) }\end{array}$ & $\begin{array}{l}\text { Marine Strategy Framework } \\
\text { Directive (MSFD) and Mari- } \\
\text { time Spatial Planning (MSP) }\end{array}$ & $\begin{array}{l}\text { DGRM is a government entity } \\
\text { of the Ministry of the Sea, a } \\
\text { central office of direct admin- } \\
\text { istration of State, with admin- } \\
\text { istrative autonomy with the } \\
\text { mission, under maritime } \\
\text { administration functions, to } \\
\text { implement and execute poli- } \\
\text { cies concerning maritime } \\
\text { safety and prevention of pol- } \\
\text { lution by ships and ensure } \\
\text { regulation, inspection, } \\
\text { national coordination and } \\
\text { control of activities developed } \\
\text { under these policies. }\end{array}$ \\
\hline
\end{tabular}


Table 2 (continued)

\begin{tabular}{l|l|l}
\hline Institution & Policy domain & Additional information \\
\hline $\begin{array}{l}\text { The Centro Regional Coordi- } \\
\text { nation and Development } \\
\text { Commission (CCDRC) }\end{array}$ & $\begin{array}{l}\text { Promote an integrated and } \\
\text { sustainable development of } \\
\text { Portugal's Centro region } \\
\text { (NUT II) }\end{array}$ & $\begin{array}{l}\text { CCDRC is tasked with coor- } \\
\text { dinating and promoting at the } \\
\text { regional level governmental } \\
\text { policies with regard to } \\
\text { Regional Planning and } \\
\text { Development, Environment, } \\
\text { Land Management, Inter- } \\
\text { Regional and Cross-Border } \\
\text { Cooperation and also support } \\
\text { local government and inter- } \\
\text { municipal associations. } \\
\text { CCDR-C's fields of interven- } \\
\text { tion also encompass manage- } \\
\text { ment of regional operational } \\
\text { programmes funded by the } \\
\text { EU, and other regional devel- } \\
\text { opment financing instruments. }\end{array}$ \\
\end{tabular}

the lack of harmonised monitoring programmes for the Water Framework Directive (WFD, 2000/60/EC) and Habitats Directive (HD, 92/43/EEC). In this context, one of the main challenges concerns the use of best available information.

\subsection{Step Three: Understand Stakeholder Objectives}

Vouga estuary Natura 2000 site governance involves a multiplicity of institutions, organisations and stakeholders, and involves articulation of programs and plans of local, regional and national levels (Teles et al. 2014; Fidélis and Carvalho 2015; Lillebø et al. (eds) 2015; Sousa et al. 2016; Sousa 2017; Fidélis et al. 2019). The Portuguese Environment Agency, through its Regional Hydrographic Administration for Portugal Centro Region (APA/ARH Centro) was engaged at a very early stage of the project, helping identify key management questions. Other stakeholders engaged at the kick-off stage of the work and contributed to the datasets that support scenario development include the Institute for Nature Conservation and Forests (ICNF, I.P.), Regional Directorate for Agriculture and Fisheries (DRAP Centro), Hydrographic Institute (IH), and Directorate-General for Marine Resources (DGRM). Stakeholder's participatory moments included two workshops (WS I and WS II) and a final seminar, where the co-created EBM plan was presented. All participants received a non-technical, open-access book in Portuguese detailing the entire EBM process and the main results. Approximately 70 stakeholders representing the four major groups, namely policy/governance, public administration, business, and non-governmental organizations, were invited to participate (Table 3). 
Table 3 Identification of key stakeholders for the planning process of EBM responses

\begin{tabular}{|c|c|}
\hline \multicolumn{2}{|l|}{ Policy/Governance } \\
\hline Environment & $\begin{array}{l}\text { APA/ARH Centro-Portuguese Environmental Agency } \\
\text { ICNF-Institute for Nature Conservation and Forests }\end{array}$ \\
\hline Fisheries and agriculture & $\begin{array}{l}\text { DRAPC-Centro Region Department of Agriculture and } \\
\text { Fisheries }\end{array}$ \\
\hline Marine & $\begin{array}{l}\text { DGRM-Directorate-General for Natural Resources, Safety } \\
\text { and Maritime Services }\end{array}$ \\
\hline \multicolumn{2}{|l|}{ Public administration } \\
\hline Regional administration & $\begin{array}{l}\text { CCDRC-The Centro Regional Coordination and Develop- } \\
\text { ment Commission } \\
\text { CIRA-Inter-municipal Community of the Aveiro Region }\end{array}$ \\
\hline $\begin{array}{l}\text { Municipalities within the Natura } \\
2000 \text { classified area }\end{array}$ & $\begin{array}{l}\text { Águeda, Albergaria-a-Velha, Anadia, Aveiro, Estarreja, } \\
\text { Ílhavo, Mira Murtosa, Oliveira do Bairro, Ovar, Vagos. }\end{array}$ \\
\hline $\begin{array}{l}\text { Parishes within the Natura } 2000 \\
\text { classified area }\end{array}$ & $\begin{array}{l}\text { E.g., Angeja, Avanca, Beduído \& Vieiros, Bunheiro, Cacia, } \\
\text { Canelas \& Fermelã, Esgueira, Espinhel, Fermentelos, } \\
\text { Gafanha Da Boa Hora, Gafanha Da Encarnação, Gafanha Da } \\
\text { Nazaré, Gafanha Do Carmo, Glória \& Vera Cruz, Murtosa, } \\
\text { Óis da Ribeira, Ouca, Ovar Union of parishes, Pardilhó, } \\
\text { Requeixo, Salreu, Santo André De Vagos, São Jacinto, São } \\
\text { Salvador, Sosa, Torreira, Vagos \& Santo António De Vagos, } \\
\text { Válega. }\end{array}$ \\
\hline \multicolumn{2}{|l|}{ Business } \\
\hline Industry & Portucel-The Navigator Company \\
\hline Tourism & $\begin{array}{l}\text { Incrível Odisseia-Moliceiros boat rides } \\
\text { Sterna-Solar boat tours and bird watching }\end{array}$ \\
\hline Agriculture & $\begin{array}{l}\text { ABBVL-Association of Beneficiaries of Baixo Vouga } \\
\text { Lagunar } \\
\text { ACRM-Association of Breeders of Marinhoa Breed } \\
\text { ALDA-Association of Agriculture of the District of Aveiro }\end{array}$ \\
\hline Fisheries & $\begin{array}{l}\text { APARA-Artisanal Fishing Association of the Region of } \\
\text { Aveiro }\end{array}$ \\
\hline Aquaculture & APA—Portuguese aquaculture association \\
\hline Services & APA—Port of Aveiro Administration (APA) \\
\hline \multicolumn{2}{|l|}{ Other } \\
\hline Local associations & $\begin{array}{l}\text { AVELA-Sailing club } \\
\text { ADERAV-Association for the study and protection of the } \\
\text { Natural and Cultural Heritage of Aveiro Region } \\
\text { CCPAV-Hunting and Fishing Club of Aveiro/Vouga }\end{array}$ \\
\hline $\begin{array}{l}\text { Non-governmental organizations } \\
\text { (NGO's) }\end{array}$ & $\begin{array}{l}\text { FAPAS_-Fund for the Protection of Wild Animals } \\
\text { GEOTA_-Study Group on Spatial Planning and Environ- } \\
\text { ment } \\
\text { LPN-League for the Protection of Nature } \\
\text { SPEA-The Portuguese Society for the Study of Birds } \\
\text { ASPEA-Portuguese Association of Environmental } \\
\text { Education }\end{array}$ \\
\hline
\end{tabular}

Source: Lillebø et al. (2019) 


\subsubsection{Stakeholders' Perception and Spatial Multi-Criteria Analysis}

At the first workshop (WS I), 17 stakeholders representing the four major groups participated, signing an informed consent agreement form, and were asked to identify the relevance of ecosystem services in Ria de Aveiro for building alternative management scenarios (Fig. 2). Participants were invited to express their opinion regarding expected beneficial effects and persistent concerns related to the current management options and contribute to the spatial multi-criteria analysis through prioritization of ecosystem services (Lillebø et al. 2019; Martínez-López et al. 2019b). This prioritization reflected stakeholders' social preferences regarding ecosystem services in order to find optimal management actions (sensu Villa et al. 2002; Martínez-López et al. 2019b). The method adopted ensures transparency of the participatory process, which is of paramount importance as different sectoral interests, such as conservationists, local users and from the business sector, like tourism, may express different priorities in relation to a set of ecosystem services of interest. This is crucial to make the participatory valuation of ES an opportunity for a more comprehensive, fair and integrative perspective for EBM (Martínez-López et al. 2019b). This socio-ecological approach illustrates how planned and structured co-developed solutions can effectively contribute and support adaptive management and conservation of coastal ecosystems (Lillebø et al. 2019).

\subsubsection{Recommendations for EBM Implementation}

At the second workshop (WS II), 15 stakeholders representing the four major groups, which signed an informed consent agreement form, were asked to identify the relevant issues that should be included in the adaptation strategy as well as the opportunities and constraints of implementation.

Participants were invited to join round-table groups (Fig. 3) following a 'world café' methodology to discuss three topics:

- Environment and ecosystem services (spatial distribution of EBM measures, identification of areas for remediation of marshes, benefits and constraints);

- Institutions and equity (identification of institutions involved, process coordinators, benefits and constraints);
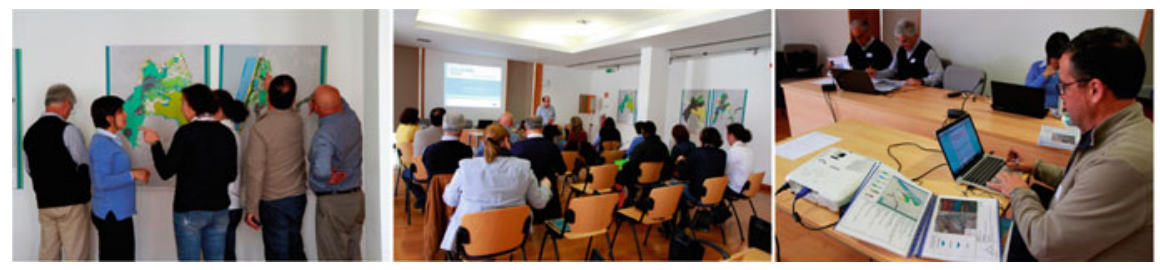

Fig. 2 Overview of WS I participatory moments: habitats spatial distribution maps; presentation of WS I objectives; spatial multi-criteria analysis for ES valuation 

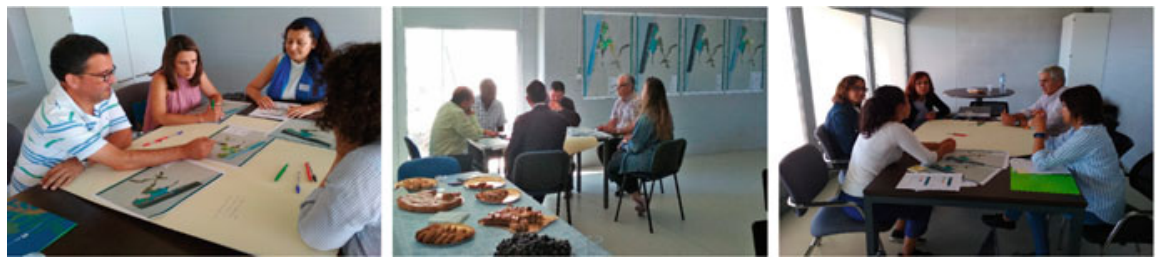

Fig. 3 Overview of WS II participatory moments: The three 'world café' sessions considered

- Operationalization and sustainable development (identification of existing activities supported by the benefits provided by marshes, business opportunities, benefits and constraints).

Stakeholders were also invited to answer the question "In which way the EBM methodology can be better or not in relation to the management approaches used until now?"

\subsection{Step Four: Understand the Social-Ecological System}

The assessment of Vouga estuary's current state included the identification of habitats, specific public and private primary human activities, and respective pressures in the entire Natura 2000 territory. To address the ecological perspective of the system, data sources from scientific publications, projects (e.g., LAGOONS EU FP7; ADAPT-MED EU FP7 ERA-NET; LTER-RAVE FCT, AQUACROSS EU H2020), national agencies (e.g., above mentioned), online platforms (e.g., Copernicus datasets) and from national/regional official reports were integrated. In order to harmonise habitats classification, all data sets (mainly following Annex I of EU Habitats Directive; Sousa et al. 2016) were converted into the EUNIS habitat classification, following the official correspondence table available at the European Environmental Agency (EEA) portal (http://eunis.eea.europa.eu/habitats.jsp). Data sets on ecosystem services (mainly following CICES, V4.3; Lillebø et al. (eds) 2015; Sousa et al. 2016) were updated and classified following the latest Common International Classification of Ecosystem Services (CICES, V5.1; https://cices.eu/) (Haines-Young and Potschin 2017; O'Higgins et al. 2019). The potential of a given habitat to supply ecosystem services was attained using a lookup table on the contribution of each EUNIS habitat compiled based on expert judgment (Teixeira et al. 2019). The identified ecosystem services were aggregated into eleven ecosystem services in order to enable spatial multi-criteria analysis by stakeholders (Table 4). This table includes the correspondence code from CICES v4.3 to 5.1, considering the identified services for the considered territory, as well as selected aggregation of services used in the scope of the participatory moments in order to optimize communication and active participation of stakeholders. 
Table 4 Assessment of ecosystem services provided by Vouga estuary: (a) provisioning; (b) regulation and maintenance; (c) cultural

\begin{tabular}{|c|c|c|c|c|c|}
\hline ES code & Group & Class & $\mathrm{v} 4.3$ & v5.1 & Subclass Ria de Aveiro \\
\hline \multicolumn{6}{|c|}{ (a) CICES section: Provisioning } \\
\hline \multirow[t]{2}{*}{$\begin{array}{l}\text { ES1 } \\
\text { Biotic } \\
\text { based } \\
\text { energy } \\
\text { sources }\end{array}$} & $\begin{array}{l}\text { Mechanical } \\
\text { energy }\end{array}$ & $\begin{array}{l}\text { Animals reared } \\
\text { to provide } \\
\text { energy (incl. } \\
\text { mechanical) }\end{array}$ & 1.3.2.1 & 1.1 .3 .3 & $\begin{array}{l}\text { Physical labour provided } \\
\text { by cattle supporting agri- } \\
\text { cultural activities }\end{array}$ \\
\hline & $\begin{array}{l}\text { Biomass- } \\
\text { based energy } \\
\text { sources }\end{array}$ & $\begin{array}{l}\text { Cultivated } \\
\text { plants (incl. } \\
\text { fungi, algae) } \\
\text { grown as a } \\
\text { source of energy } \\
\text { I Wild plants } \\
\text { (terrestrial and } \\
\text { aquatic, incl. } \\
\text { fungi, algae) } \\
\text { used as a source } \\
\text { of energy }\end{array}$ & 1.3 .1 .1 & $\begin{array}{l}1.1 .1 .3 \\
\& \\
1.1 .5 .3\end{array}$ & $\begin{array}{l}\text { Not applicable at the } \\
\text { selected management area }\end{array}$ \\
\hline $\begin{array}{l}\text { ES2 } \\
\text { Abiotic } \\
\text { energy } \\
\text { sources }\end{array}$ & $\begin{array}{l}\text { Renewable } \\
\text { abiotic } \\
\text { energy } \\
\text { sources }\end{array}$ & $\begin{array}{l}\text { Freshwater sur- } \\
\text { face water used } \\
\text { as an energy } \\
\text { source I Coastal } \\
\text { and marine } \\
\text { water used as } \\
\text { energy source }\end{array}$ & N/A & $\begin{array}{l}4.2 .1 .3 \\
\& \\
4.2 .1 .4\end{array}$ & $\begin{array}{l}\text { Not applicable at the } \\
\text { selected management area }\end{array}$ \\
\hline $\begin{array}{l}\text { ES3 } \\
\text { Biotic } \\
\text { materials }\end{array}$ & Biomass & $\begin{array}{l}\text { Fibres and other } \\
\text { materials from } \\
\text { wild plants/ani- } \\
\text { mals for direct } \\
\text { use or } \\
\text { processing (excl. } \\
\text { genetic } \\
\text { materials) }\end{array}$ & $\begin{array}{l}1.2 .2 .1 \\
\& \\
1.2 .2 .2\end{array}$ & $\begin{array}{l}1.1 .5 .2 \\
\& \\
1.1 .6 .2\end{array}$ & $\begin{array}{l}\text { Reeds seasonally } \\
\text { harvested } \\
\text { Worms collected in inter- } \\
\text { tidal mudflats and used as } \\
\text { bait } \\
\text { Macroalgae are collected } \\
\text { for in-situ aquaculture } \\
\text { Seagrasses and } \\
\text { macroalgae ("moliço") } \\
\text { harvesting } \\
\text { Sea rush used as cattle } \\
\text { bedding and then as a } \\
\text { fertilizer }\end{array}$ \\
\hline \multirow[t]{2}{*}{$\begin{array}{l}\text { ES4 } \\
\text { Abiotic } \\
\text { materials }\end{array}$} & Non-metallic & $\begin{array}{l}\text { Mineral sub- } \\
\text { stances used for } \\
\text { material } \\
\text { purposes }\end{array}$ & N/A & 4.3.1.2 & Sand extraction \\
\hline & Water & $\begin{array}{l}\text { Surface waterl } \\
\text { ground water } \\
\text { (and subsurface) } \\
\text { used as a mate- } \\
\text { rial } \\
\text { (non-drinking } \\
\text { purposes) }\end{array}$ & $\begin{array}{l}1.2 .2 .1 \\
\& \\
1.2 .2 .2\end{array}$ & $\begin{array}{l}4.2 .1 .2 \\
\& \\
4.2 .2 .2\end{array}$ & $\begin{array}{l}\text { The lagoon provides sur- } \\
\text { face water for salt produc- } \\
\text { tion and forest-fire control, } \\
\text { and ground water for } \\
\text { inland aquaculture, agri- } \\
\text { culture, livestock, urban } \\
\text { and industrial purposes }\end{array}$ \\
\hline
\end{tabular}


Table 4 (continued)

\begin{tabular}{|c|c|c|c|c|c|}
\hline ES code & Group & Class & $\mathrm{v} 4.3$ & v5.1 & Subclass Ria de Aveiro \\
\hline \multirow[t]{4}{*}{$\begin{array}{l}\text { ES5 } \\
\text { Nutritional } \\
\text { biotic } \\
\text { substances }\end{array}$} & \multirow[t]{4}{*}{ Biomass } & $\begin{array}{l}\text { Wild plants (ter- } \\
\text { restrial and } \\
\text { aquatic, incl. } \\
\text { fungi, algae) } \\
\text { used for } \\
\text { nutrition }\end{array}$ & 1.1.1.3 & 1.1 .5 .1 & $\begin{array}{l}\text { Wild glasswort Salicornia } \\
\text { sp. harvested and sold as a } \\
\text { gourmet product }\end{array}$ \\
\hline & & $\begin{array}{l}\text { Wild animals } \\
\text { used for nutri- } \\
\text { tional purposes }\end{array}$ & 1.1.1.4 & 1.1.6.1 & $\begin{array}{l}\text { Fish and shellfish: lamprey } \\
\text { Petromyzon marinus, } \\
\text { European eel Anguilla } \\
\text { anguilla, allis shad Alosa } \\
\text { alosa, clams Ruditapes } \\
\text { decussatus and Venerupis } \\
\text { corrugata, cockle } \\
\text { Cerastoderma edule cut- } \\
\text { tlefish Sepia officinalis }\end{array}$ \\
\hline & & $\begin{array}{l}\text { Plants cultivated } \\
\text { by in-situ aqua- } \\
\text { culture grown } \\
\text { for nutritional } \\
\text { purposes }\end{array}$ & 1.1.1.5 & 1.1.2.1 & Macroalgae farming \\
\hline & & $\begin{array}{l}\text { Animals reared } \\
\text { by } i n \text {-situ aqua- } \\
\text { culture for nutri- } \\
\text { tional purposes }\end{array}$ & 1.1.1.6 & 1.1.4.1 & $\begin{array}{l}\text { Aquaculture farms of } \\
\text { marine fish and bivalves }\end{array}$ \\
\hline \multirow[t]{2}{*}{$\begin{array}{l}\text { ES6 } \\
\text { Nutritional } \\
\text { abiotic } \\
\text { substances }\end{array}$} & Mineral & $\begin{array}{l}\text { Mineral sub- } \\
\text { stances used for } \\
\text { nutritional } \\
\text { purposes }\end{array}$ & N/A & 4.3.1.1 & $\begin{array}{l}\text { Marine salt extraction (salt } \\
\text { pans) }\end{array}$ \\
\hline & Water & $\begin{array}{l}\text { Surface water } \\
\text { for drinking }\end{array}$ & 1.1.2.1 & 4.2.1.1 & $\begin{array}{l}\text { Not applicable at the } \\
\text { selected management area }\end{array}$ \\
\hline
\end{tabular}

(b) CICES section: Regulation and maintenance

\begin{tabular}{l|l|l|l|l|l}
\hline $\begin{array}{l}\text { ES7 } \\
\text { Mediation } \\
\text { of flows }\end{array}$ & Mass flows & $\begin{array}{l}\text { Control of ero- } \\
\text { sion rates I Buff- } \\
\text { ering and } \\
\text { attenuation of } \\
\text { mass movement }\end{array}$ & $\begin{array}{l}2.2 .1 .1 \\
\&\end{array}$ & $\begin{array}{l}2.2 .1 .1 \\
\text { \& } \\
2.2 .1 .2\end{array}$ & $\begin{array}{l}\text { Overall, coastal dunes, salt } \\
\text { marshes and seagrass } \\
\text { meadows contribute to } \\
\text { maintain the lagoon } \\
\text { integrity }\end{array}$ \\
\cline { 2 - 5 } & Liquid flows & $\begin{array}{l}\text { Hydrological } \\
\text { cycle and water } \\
\text { flow regulation } \\
\text { (incl. flood con- } \\
\text { trol and coastal } \\
\text { protection) }\end{array}$ & $\begin{array}{l}2.2 .2 .1 \\
\& \\
2.2 .2 .2\end{array}$ & 2.2 .1 .3 & $\begin{array}{l}\text { Seagrass meadows and } \\
\text { salt marshes reduce sedi- } \\
\text { ment resuspension and } \\
\text { turbidity in the water col- } \\
\text { umn, contributing to } \\
\text { increase the light avail- } \\
\text { ability in the water column } \\
\text { São Jacinto dunes, salt } \\
\text { marshes and reeds provide } \\
\text { resilience to extreme } \\
\text { weather events and act as } \\
\text { physical buffering of cli- } \\
\text { mate change }\end{array}$ \\
\hline
\end{tabular}


Table 4 (continued)

\begin{tabular}{|c|c|c|c|c|c|}
\hline ES code & Group & Class & $\mathrm{v} 4.3$ & v5.1 & Subclass Ria de Aveiro \\
\hline \multirow[t]{2}{*}{$\begin{array}{l}\text { ES8 } \\
\text { Mediation } \\
\text { of waste } \\
\text { toxics and } \\
\text { other } \\
\text { nuisances }\end{array}$} & $\begin{array}{l}\text { Mediation } \\
\text { by biota I } \\
\text { Mediation } \\
\text { by } \\
\text { ecosystems }\end{array}$ & $\begin{array}{l}\text { Bio-remediation } \\
\text { by micro- } \\
\text { organisms, } \\
\text { algae, plants, } \\
\text { and animals }\end{array}$ & $\begin{array}{l}2.1 .1 .1 \\
\& \\
2.1 .1 .2\end{array}$ & 2.1 .1 .1 & $\begin{array}{l}\text { Bio-remediation by eco- } \\
\text { system components (e.g., } \\
\text { halophytes); Decomposi- } \\
\text { tion/mineralisation pro- } \\
\text { cesses of plant material } \\
\text { mediated by microorgan- } \\
\text { isms; Biological filtration } \\
\text { by oysters, clams and } \\
\text { mussels in aquaculture and } \\
\text { by wild animals }\end{array}$ \\
\hline & & $\begin{array}{l}\text { Filtration/ } \\
\text { sequestration/ } \\
\text { storage/accumu- } \\
\text { lation by micro- } \\
\text { organisms, } \\
\text { algae, plants, } \\
\text { and animals I } \\
\text { Dilution by } \\
\text { freshwater and } \\
\text { marine } \\
\text { ecosystems }\end{array}$ & $\begin{array}{l}2.1 .1 .2 \\
\& \\
2.1 .2 .1 \\
\& \\
2.1 .2 .2\end{array}$ & $\begin{array}{l}2.1 .1 .2 \\
\& \\
5.1 .1 .1\end{array}$ & $\begin{array}{l}\text { Bio-physicochemical fil- } \\
\text { tration/sequestration/stor- } \\
\text { age/accumulation of } \\
\text { pollutants by the lagoon } \\
\text { habitats; Adsorption and } \\
\text { binding of metals and } \\
\text { organic compounds in } \\
\text { ecosystems, as a result of } \\
\text { combination of biotic and } \\
\text { abiotic factors; Hydrody- } \\
\text { namic dilution of pollut- } \\
\text { ants (tidal action) }\end{array}$ \\
\hline \multirow[t]{4}{*}{$\begin{array}{l}\text { ES9 } \\
\text { Mainte- } \\
\text { nance of } \\
\text { physical } \\
\text { chemical } \\
\text { biological } \\
\text { conditions }\end{array}$} & $\begin{array}{l}\text { Lifecycle } \\
\text { maintenance, } \\
\text { habitat, gene } \\
\text { pool } \\
\text { protection }\end{array}$ & $\begin{array}{l}\text { Maintaining } \\
\text { nursery } \\
\text { populations and } \\
\text { habitats (incl. } \\
\text { gene pool } \\
\text { protection) }\end{array}$ & 2.3.1.2 & 2.2 .2 .3 & $\begin{array}{l}\text { Maintaining nursery habi- } \\
\text { tat for fisheries species and } \\
\text { commercial invertebrates; } \\
\text { Seagrasses, salt marshes } \\
\text { including extended areas } \\
\text { of reeds, intertidal mud- } \\
\text { flats, sand flats and salt } \\
\text { pans }\end{array}$ \\
\hline & $\begin{array}{l}\text { Pest, disease } \\
\text { control }\end{array}$ & $\begin{array}{l}\text { Pest control } \\
\text { (incl. invasive } \\
\text { species) I Dis- } \\
\text { ease control }\end{array}$ & $\begin{array}{l}2.3 .2 .1 \\
\& \\
2.3 .2 .2\end{array}$ & $\begin{array}{l}2.2 .3 .1 \\
\& \\
2.2 .3 .2\end{array}$ & $\begin{array}{l}\text { Maintaining the system in } \\
\text { a healthy status (e.g., from } \\
\text { alien species or diseases) }\end{array}$ \\
\hline & $\begin{array}{l}\text { Soil forma- } \\
\text { tion, } \\
\text { composition }\end{array}$ & $\begin{array}{l}\text { Decomposition } \\
\text { and fixing pro- } \\
\text { cesses and their } \\
\text { effect on soil } \\
\text { quality }\end{array}$ & 2.3 .3 .2 & 2.2 .4 .2 & $\begin{array}{l}\text { Decomposition of biologi- } \\
\text { cal materials and their } \\
\text { incorporation in sediments }\end{array}$ \\
\hline & $\begin{array}{l}\text { Water } \\
\text { conditions }\end{array}$ & $\begin{array}{l}\text { Regulation of } \\
\text { the chemical } \\
\text { condition of salt } \\
\text { waters by living } \\
\text { processes }\end{array}$ & 2.3.4.2 & 2.2.5.2 & $\begin{array}{l}\text { Water purification by tidal } \\
\text { wetlands, including } \\
\text { seagrass meadows and salt } \\
\text { marshes }\end{array}$ \\
\hline
\end{tabular}


Table 4 (continued)

\begin{tabular}{|c|c|c|c|c|c|}
\hline \multirow[t]{3}{*}{ ES code } & Group & Class & $\mathrm{v} 4.3$ & v5.1 & Subclass Ria de Aveiro \\
\hline & \multirow[t]{2}{*}{$\begin{array}{l}\text { Atmospheric } \\
\text { composition } \\
\text { and climate } \\
\text { regulation I } \\
\text { Gaseous/air } \\
\text { flows }\end{array}$} & $\begin{array}{l}\text { Regulation of } \\
\text { chemical com- } \\
\text { position of } \\
\text { atmosphere and } \\
\text { oceans I Mainte- } \\
\text { nance and regu- } \\
\text { lation by } \\
\text { inorganic natu- } \\
\text { ral chemical and } \\
\text { physical } \\
\text { processes }\end{array}$ & 2.3.5.1 & $\begin{array}{l}2.2 .6 .1 \\
\& \\
5.2 .2 .1\end{array}$ & $\begin{array}{l}\text { Global climate regulation } \\
\text { by greenhouse gas/carbon } \\
\text { sequestration by seagrass } \\
\text { meadows and salt } \\
\text { marshes, water columns } \\
\text { and storage in sediments } \\
\text { and their biota; Transport } \\
\text { of carbon into oceans }\end{array}$ \\
\hline & & $\begin{array}{l}\text { Regulation of } \\
\text { temperature and } \\
\text { humidity, } \\
\text { including venti- } \\
\text { lation and } \\
\text { transpiration }\end{array}$ & $\begin{array}{l}2.3 .5 .2 \\
\& \\
2.2 .3 .2\end{array}$ & 2.2 .6 .2 & $\begin{array}{l}\text { Micro and regional cli- } \\
\text { mate regulation by the Ria } \\
\text { de Aveiro lagoon water } \\
\text { body that includes the } \\
\text { Vouga estuary }\end{array}$ \\
\hline \multicolumn{6}{|c|}{ (cont.) (c) CICES section: Cultural } \\
\hline \multirow[t]{3}{*}{$\begin{array}{l}\text { ES10 } \\
\text { Physical \& } \\
\text { intellectual } \\
\text { interactions } \\
\text { with biota, } \\
\text { ecosys- } \\
\text { tems, land } \\
\text { \& sea- } \\
\text { scapes } \\
\text { environ- } \\
\text { mental } \\
\text { settings }\end{array}$} & \multirow[t]{2}{*}{$\begin{array}{l}\text { Physical and } \\
\text { experiential } \\
\text { interactions }\end{array}$} & $\begin{array}{l}\text { Characteristics } \\
\text { of living sys- } \\
\text { tems that enable } \\
\text { activities pro- } \\
\text { moting health, } \\
\text { recuperation or } \\
\text { enjoyment } \\
\text { through passive } \\
\text { or observational } \\
\text { interactions }\end{array}$ & 3.1 .1 .1 & $\begin{array}{l}3.1 .1 .1 \\
\& \\
6.1 .1 .1\end{array}$ & $\begin{array}{l}\text { In-situ bird watching of: } \\
\text { Resident birds, e.g., } \\
\text { Charadrius alexandrinus } \\
\text { Migratory birds, e.g., } \\
\text { Himantopus himantopus }\end{array}$ \\
\hline & & $\begin{array}{l}\text { Characteristics } \\
\text { of living sys- } \\
\text { tems that that } \\
\text { enable activities } \\
\text { promoting } \\
\text { health, recupera- } \\
\text { tion or enjoy- } \\
\text { ment through } \\
\text { active or } \\
\text { immersive inter- } \\
\text { actions I Natural, } \\
\text { abiotic charac- } \\
\text { teristics of } \\
\text { nature that } \\
\text { enable active or } \\
\text { passive physical } \\
\text { and experiential } \\
\text { interactions }\end{array}$ & 3.1 .1 .2 & $\begin{array}{l}3.1 .1 .2 \\
\& \\
6.1 .1 .1\end{array}$ & $\begin{array}{l}\text { Walking, diving, biking, } \\
\text { sailing, boating, kite surf- } \\
\text { ing, windsurfing, kayak- } \\
\text { ing, swimming, leisure } \\
\text { fishing (angling) and lei- } \\
\text { sure hunting. }\end{array}$ \\
\hline & $\begin{array}{l}\text { Intellectual } \\
\text { and repre- } \\
\text { sentative } \\
\text { interactions }\end{array}$ & $\begin{array}{l}\text { Characteristics } \\
\text { of living sys- } \\
\text { tems that enable } \\
\text { scientific }\end{array}$ & 3.1 .2 .1 & $\begin{array}{l}3.1 .2 .1 \\
\& \\
6.1 .2 .1\end{array}$ & $\begin{array}{l}\text { Ria de Aveiro is subject } \\
\text { matter for research }\end{array}$ \\
\hline
\end{tabular}


Table 4 (continued)

\begin{tabular}{|c|c|c|c|c|c|}
\hline ES code & Group & Class & $\mathrm{v} 4.3$ & v5.1 & Subclass Ria de Aveiro \\
\hline & & $\begin{array}{l}\text { investigation or } \\
\text { the creation of } \\
\text { traditional eco- } \\
\text { logical knowl- } \\
\text { edge I Natural, } \\
\text { abiotic charac- } \\
\text { teristics of } \\
\text { nature that } \\
\text { enable intellec- } \\
\text { tual interactions }\end{array}$ & & & \\
\hline & & $\begin{array}{l}\text { Characteristics } \\
\text { of living systems } \\
\text { that enable edu- } \\
\text { cation and } \\
\text { training }\end{array}$ & 3.1.2.2 & 3.1.2.2 & $\begin{array}{l}\text { Natural and cultural heri- } \\
\text { tage of the lagoon are } \\
\text { subject matter of education } \\
\text { (e.g., guided boat tours in } \\
\text { Ria, science activities in } \\
\text { the summer with the sup- } \\
\text { port of the University of } \\
\text { Aveiro, BioRia Environ- } \\
\text { mental trails, Natural } \\
\text { Reserve of São Jacinto } \\
\text { Dunes, "Marinha da } \\
\text { Troncalhada" salt pan } \\
\text { ecomuseum, "Santiago da } \\
\text { Fonte" salt pan (belongs } \\
\text { Aveiro University), ship- } \\
\text { museum "Santo André" } \\
\text { (an extension of the Mari- } \\
\text { time Museum of Ílhavo); } \\
\text { "Casa Gafanhoa" munici- } \\
\text { pal museum (testimony of } \\
\text { the rural livelihoods of } \\
\text { Ílhavo municipality) }\end{array}$ \\
\hline & & $\begin{array}{l}\text { Characteristics } \\
\text { of living sys- } \\
\text { tems that are } \\
\text { resonant in } \\
\text { terms of culture } \\
\text { or heritage }\end{array}$ & 3.1 .2 .3 & 3.1.2.3 & $\begin{array}{l}\text { Archaeological sites (e.g., } \\
\text { shipwrecks, ship hull, and } \\
\text { other isolated findings); } \\
\text { Traditional architecture } \\
\text { (e.g., "Palheiros", "Casa } \\
\text { Gafanhoa"); Traditional } \\
\text { boats (e.g., "Moliceiro", } \\
\text { "Bateira", "Mercantel"); } \\
\text { Traditional activities (e.g., } \\
\text { salt production) }\end{array}$ \\
\hline & & $\begin{array}{l}\text { Characteristics } \\
\text { of living sys- } \\
\text { tems that enable } \\
\text { aesthetic } \\
\text { experiences }\end{array}$ & 3.1 .2 .5 & 3.1.2.4 & $\begin{array}{l}\text { Sense of place; Artistic } \\
\text { representations of nature } \\
\text { (e.g., ceramic tiles, painted } \\
\text { shells); Inspiration for } \\
\text { some painters and writers, } \\
\text { interested in the history } \\
\text { and heritage of the lagoon } \\
\text { and its users }\end{array}$ \\
\hline
\end{tabular}


Table 4 (continued)

\begin{tabular}{|c|c|c|c|c|c|}
\hline ES code & Group & Class & $\mathrm{v} 4.3$ & v5.1 & Subclass Ria de Aveiro \\
\hline \multirow[t]{3}{*}{$\begin{array}{l}\text { ES11 } \\
\text { Spiritual } \\
\text { symbolic } \\
\text { \& other } \\
\text { interactions } \\
\text { with biota } \\
\text { ecosystems } \\
\text { \& land sea- } \\
\text { scapes } \\
\text { environ- } \\
\text { mental } \\
\text { settings }\end{array}$} & $\begin{array}{l}\text { Spiritual } \\
\text { and/or } \\
\text { emblematic }\end{array}$ & $\begin{array}{l}\text { Elements of liv- } \\
\text { ing systems used } \\
\text { for entertain- } \\
\text { ment or repre- } \\
\text { sentation I } \\
\text { Natural, abiotic } \\
\text { characteristics of } \\
\text { nature that } \\
\text { enable spiritual, } \\
\text { symbolic and } \\
\text { other } \\
\text { interactions }\end{array}$ & 3.1.2.4 & $\begin{array}{l}3.2 .1 .3 \\
\& \\
6.2 .1 .1\end{array}$ & $\begin{array}{l}\text { Ex-situ experiences } \\
\text { through local festivals } \\
\text { related with the lagoon's } \\
\text { products and activities } \\
\text { (e.g., "Festa da Ria" sum- } \\
\text { mer festival with tradi- } \\
\text { tional "moliceiro" boats } \\
\text { race; Cod fish festival; Eel } \\
\text { and "ovos moles" from } \\
\text { Aveiro; food festival; } \\
\text { International marine salt } \\
\text { festival; "FARAV" hand- } \\
\text { craft festival, Lamprey } \\
\text { festival, Allis shad (Alosa } \\
\text { alosa) festival }\end{array}$ \\
\hline & $\begin{array}{l}\text { Other cul- } \\
\text { tural outputs }\end{array}$ & $\begin{array}{l}\text { Characteristics } \\
\text { or features of } \\
\text { living systems } \\
\text { that have an } \\
\text { existence value }\end{array}$ & 3.2.2.1 & 3.2.2.1 & $\begin{array}{l}\text { Enjoyment provided by } \\
\text { salt pans, salt marshes, } \\
\text { seagrasses and wild } \\
\text { species }\end{array}$ \\
\hline & & $\begin{array}{l}\text { Characteristics } \\
\text { or features of } \\
\text { living systems } \\
\text { that have an } \\
\text { option or } \\
\text { bequest value }\end{array}$ & 3.2.2.2 & 3.2.2.2 & $\begin{array}{l}\text { Willingness to preserve } \\
\text { salt pans, salt marshes, } \\
\text { seagrasses and wild spe- } \\
\text { cies for future generations }\end{array}$ \\
\hline
\end{tabular}

Equivalence of CICES classification (Group v4.3 \& Class v5.1) to aggregated ecosystem services (ES code) used at the participatory moments in the scope of the EBM approach. Note: the assessment included the biologically mediated process and the abiotic outputs

Adapted from Martínez-López et al. (2019b) and O’Higgins et al. (2019)

Analysis of ecosystem services valuations (Martínez-López et al. 2019a) revealed two major stakeholder opinion groups, stating within group more similar preferences regarding ecosystem services, and whose composition was heterogeneous and not related to specific stakeholder groups identified. Weights in the spatial multi-criteria analysis in the selected Natura 2000 area took into account the mean of the ecosystem services scores given by individuals in the same opinion group. However, in the absence of strong and significant differentiation among the two opinion groups' valuations, a compromise map was generated, representing the average prioritization of ecosystem services by all participants.

Overall, the stakeholders' valuation clearly revealed the importance attributed to ecosystem services directly provided by water (freshwater, transitional, and coastal/ marine), with special emphasis on the lagoon ecosystem (Lillebø et al. 2019). However, different preference patterns may arise if the focus is set on smaller scales or in specific areas of the case study as also demonstrated by Martínez-López et al. (2019a). 
The final ecosystem services valuation maps were then compared with areas that will be affected by the dredging programme and flood bank. The mapping process involved the combination of several lines of evidence. The spatial explicit information on habitat mapping, human activities, and identified ecosystem services (Teixeira et al. 2019) was considered along with stakeholder's ecosystem services prioritization, the ecosystem services provisioning risk assessment (Lillebø et al. 2018), and stakeholders' persisting concerns regarding the foreseen measures, crucial to effectively highlight the most critical areas for the implementation of EBM management measures.

\subsection{Step Five: Specification of Relevant EBM Solutions (as Part of the EBM Cycle)}

Specification of relevant EBM solutions requires a clear definition of each component of Drivers-Pressures-State relationships as well as their causal links (Gómez et al. 2017; Teixeira et al. 2018). The applied approach, after Gómez et al. (2017) links the socio-economic and the ecological systems by making a clear distinction between:

- "the activities that benefit from the provision of natural goods and services for the production of final goods and services that are of direct concern for human welfare;

- the drivers of pressures affecting ecosystems, represented by the specific demands of naturally provided goods and services in the quantity, quality required at specific places and moments of time;

- the primary activities that (co-) produce goods and services provided by natural capital that are of direct concern to explain the pressures over ecosystems."

The assessment of the current state included the identification of the specific primary activities and the respective pressures considering the identified habitats (see Sect. 3.4). The specification of the relevant EBM solution requested the following:

- Identify a baseline scenario, incorporating the considered management measures;

- Formulate objectives related to the unintended impacts on biodiversity;

- Screen measures and instruments to understand ecological and social components;

- Construct a narrative reflecting management measures, stakeholders' perception of ecosystem services valuation, and science-based knowledge generated, to support planning the EBM response;

- Evaluate proposed habitat restoration measures using EBM criteria, taking into consideration policies and feasibility, to show that compliance is achievable. 


\subsection{Step Six: Evaluate the EBM Solutions}

After co-defining EBM management alternatives, the following step concerns the co-evaluation of proposed management alternatives, following Piet et al. (2017), by applying established pre-screening criteria: effectiveness (i.e., hitting the target); efficiency (making the most for human well-being); and equity and fairness (i.e., sharing the benefits). This allowed to determine the performance of the proposed EBM measures compared to a baseline situation "in terms of environmental impacts, subsequent costs and benefits of human wellbeing at individual and collective levels, and the distribution of these impacts and costs throughout society" (Piet et al. 2017).

\section{The Co-created EBM Plan for the Vouga Estuary Natura 2000 Site}

\subsection{The Governance Boundary}

As for other socio-ecological systems the Vouga estuary governance is complex, involving several institutions with multi-level and multi-spatial scales of governance (Lillebø et al. (eds) 2015; Sousa 2017; Fidélis et al. 2019), with different governance models applied for integrated water resource management (Teles et al. 2014; Fidélis et al. 2019). Fidélis et al. (2019) assessed alternative governance models for Ria de Aveiro considering "the organizational settings established to accommodate the different policy priorities existing in an estuary, their decision-making tools and processes, responsibility boundaries, stakeholder involvement schemes, and the means to face the challenges of a dynamic and vulnerable system". This analysis, built upon Teles et al. (2014), presents an in-depth discussion highlighting the need for a paradigm change that implies high levels of institutional reforms. The authors concluded that "regardless of the model adopted, it is crucial to derive a stable collaborative framework of decision-making in order to integrate action plans and policies for integrated water resource management in estuarine areas" which is in line with the proposed approach to specifically address co-development of EBM planning in the Vouga estuary for the mitigation of unintended impacts on biodiversity.

\subsection{Policy Objectives, Synergies, and Gaps}

The assessed EU water-related and Nature Directives showed that Natura 2000 network sites should be 'managed in a sustainable manner, both ecologically and economically', involving local policy-makers and stakeholders. Priorities identified for improvement include: 
- Harmonisation and integration of monitoring programmes of Water Framework and Habitats Directive in water-dependent Natura 2000 sites;

- Development of the Vouga estuary land use and management plan aiming to conserve and promote sustainable use of water resources, ecosystem functions, integrated management, and coordination between various territorial management instruments;

- Enhancement communication among entities and foster involvement and active participation of land users and landowners.

\subsection{Understand Stakeholder Objectives}

Stakeholders representing different sectoral interests or activities share key objectives to: foster sustainable development of economic activities and preservation of aquatic biodiversity; integrate territorial management instruments; enhance participatory management; and co-create adaptive management solutions. There were a number of aspects that stakeholders identified, both with respect to major beneficial effects and persisting concerns, regarding Ria de Aveiro and the Vouga estuary from the first workshop:

Ecosystems biodiversity-Stakeholders highlighted habitat richness as important and revealed concerns regarding impact of dredging on seagrasses, saltmarshes, and juvenile fauna due to changes in eco-hydrology and potential mobilization of contaminants due to dredging.

Water management-The need for targeted dredging (e.g., oriented for habitats, housing, and infrastructure) was acknowledged but concerns were expressed regarding changes at the system hydrology, specifically increase in tidal prism due to dredging. Consequently, low navigability in inner channels during low tide and the increase of ocean water volume in the lagoon during high tide are of concern.

Agriculture-Concerns were related to the loss of traditional agricultural activities that enable ecosystems and biodiversity maintenance, which could benefit from incentives and compensations. The stimulus for agriculture was acknowledged. To this end the need for the completion of the flood bank and the increase in agricultural land area was set forward.

Fisheries and aquaculture-Stakeholders highpoint the relevance of this coastal system to migratory species with high socio-economic value, such as sea lamprey (Petromyzon marinus), European eel (Anguilla anguilla) and allis shad (Alosa alosa). Concerns regarding these activities could be overcome through incentives and compensations for maintenance of traditional aquaculture activities that maintained ecosystems and biodiversity.

Tourism and recreational activities-Tourism was seen as an opportunity, namely marked walking trails, supporting recreational activities and ecotourism. The increased navigability conditions inside the lagoon after planned dredging will 
promote recreational boating and touristic activities, although some concerns remain as increases in water current velocity is expected to alter habitats used for other touristic and recreational purposes (e.g., loss of lagoon inner mud/sandflats used either as beaches or preferential bird watching sites).

Transversal-Other beneficial aspects and persisting concerns were considered transversal to the previous issues, specifically benefits from development of different sectoral economic activities; as well as the recognised scientific knowledge on Ria de Aveiro natural capital. Main concerns were due to lack of communication, which is paramount for integrated management, the need for information and awareness in the municipal councils, as well as landowner involvement, and lack of regulatory surveillance of activities within Ria de Aveiro.

Considering the management measures to be implemented, stakeholder knowledge and perceptions supported baseline scenario development, formulation of objectives related to the unintended impacts on biodiversity, and narratives of possible futures to support planning the EBM response.

\subsection{Understand the Social-Ecological System}

To understand the impact of the dredging in the Ria de Aveiro, we identified key human activities (Fig. 4), resulting pressures, habitats (see Fig. 5 for EUNIS habitat types), and how these support valuable ecosystem services. Relevant activities are related to boating, diving, shipping, coastal defence, port facilities, saltworks, fishing, bait digging, aquaculture, agriculture, livestock and forestry.

The linkage framework for Drivers and Pressures considering the Vouga coastal watershed is shown in Fig. 6. It can be seen that transitional waters realm, which includes the EUNIS habitats type code A, is affected by several pressures resulting from specific human activities, including capital dredging and maintenance dredging. The linkage chain associated with these activities reflects the complexity of linkages relating activities with associated pressures that determine functions and services provided by the habitats they impact. Figure 7 highlights the linkage framework for Drivers-Pressures-Ecosystem Component-Ecosystem Function and Ecosystem Services in the Vouga estuary. The management options 'behind' the baseline scenario were plotted considering the aggregated primary activities of dredging (representing the dredging programme) and flood and coastal defence (representing the extension of the flood-bank) and ecosystems components, functions and services. These management options are also relevant for other activities, namely cultivation of crops and livestock. The extension of the flood bank will disable surface saltwater intrusion into Baixo Vouga allowing recovery of arable land for agriculture and livestock. Furthermore, they will also affect input of organic matter and litter into the aquatic environment. As such, changes in the mechanical and physical structuring will affect biogeochemical cycles and production (primary 


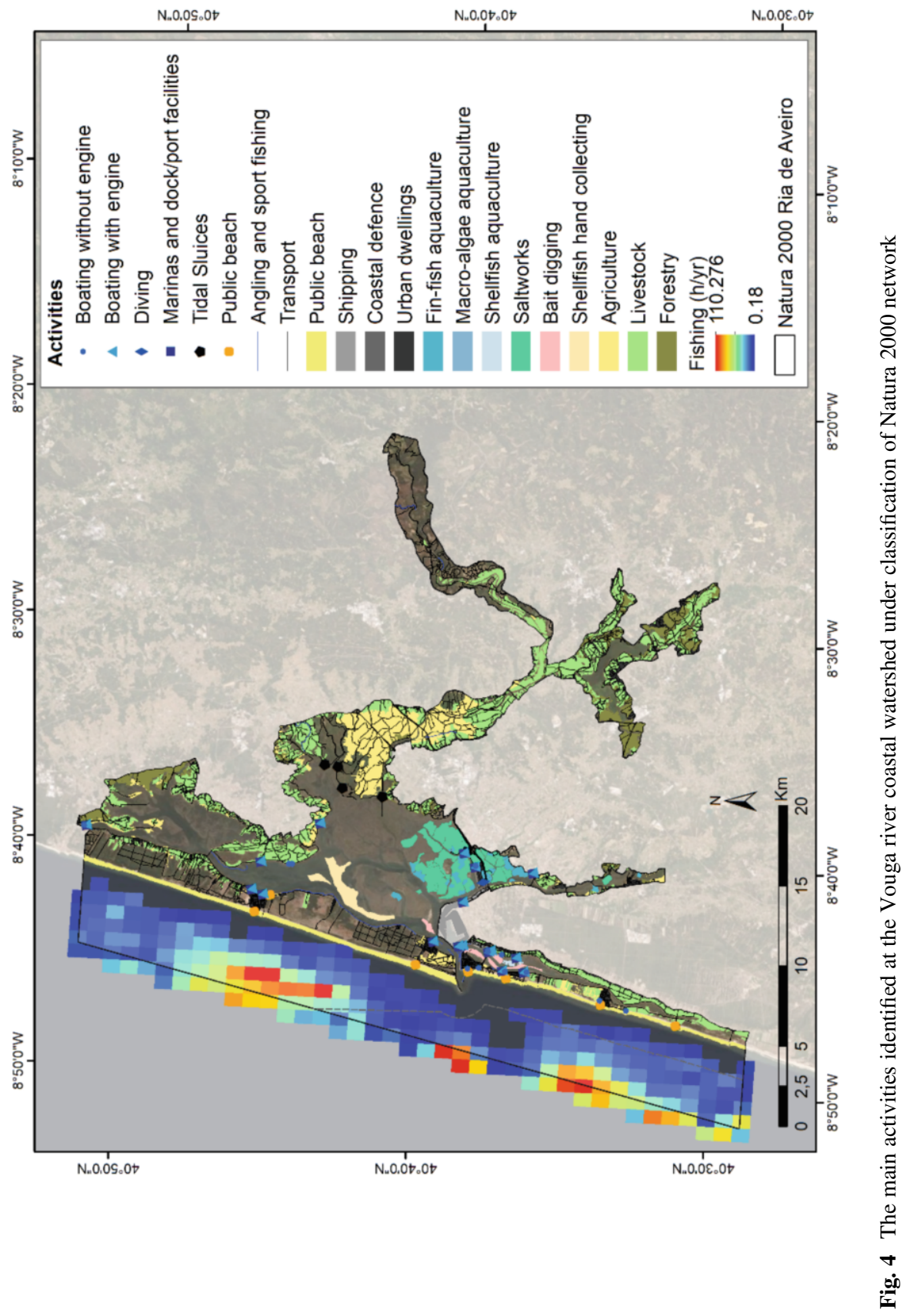



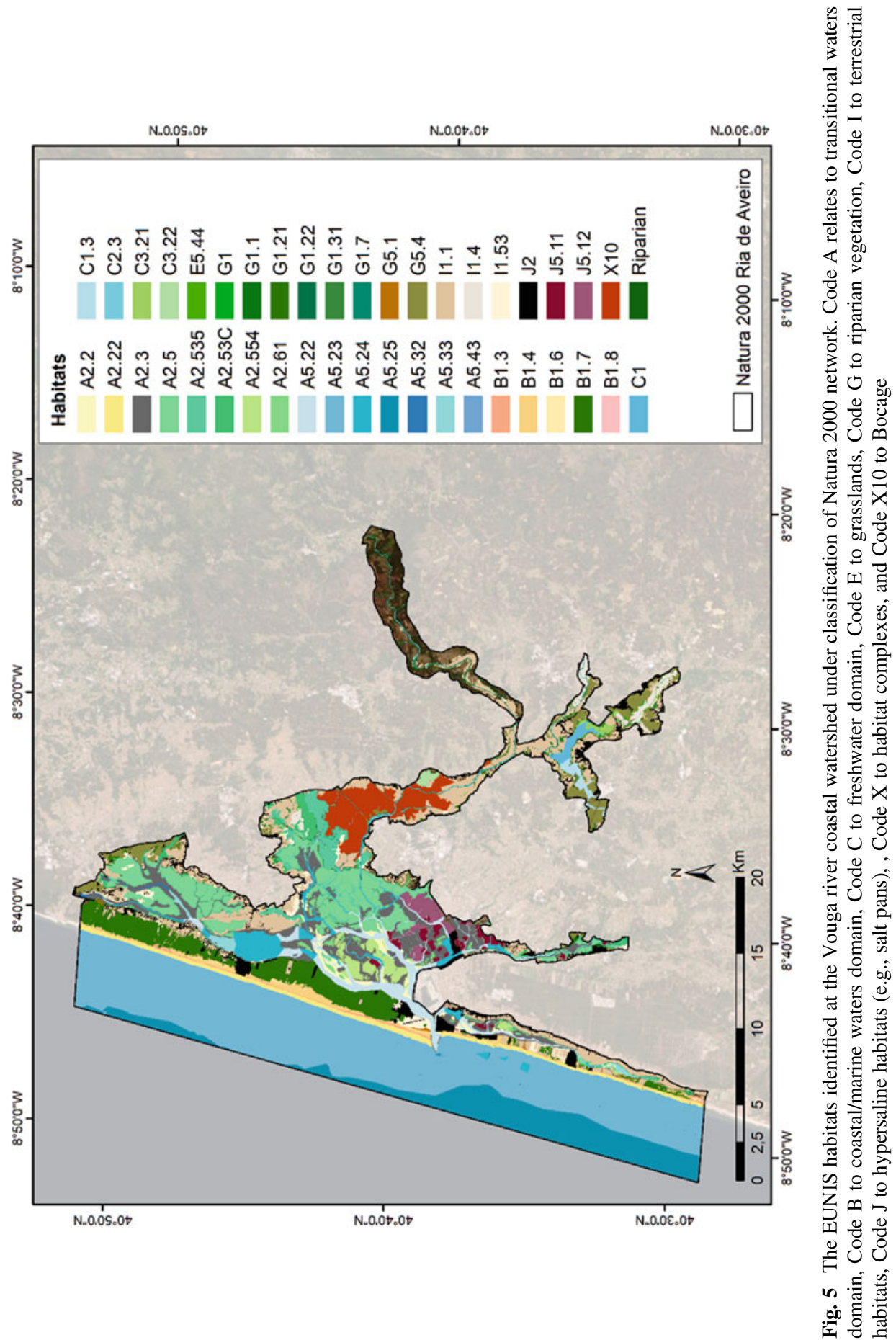


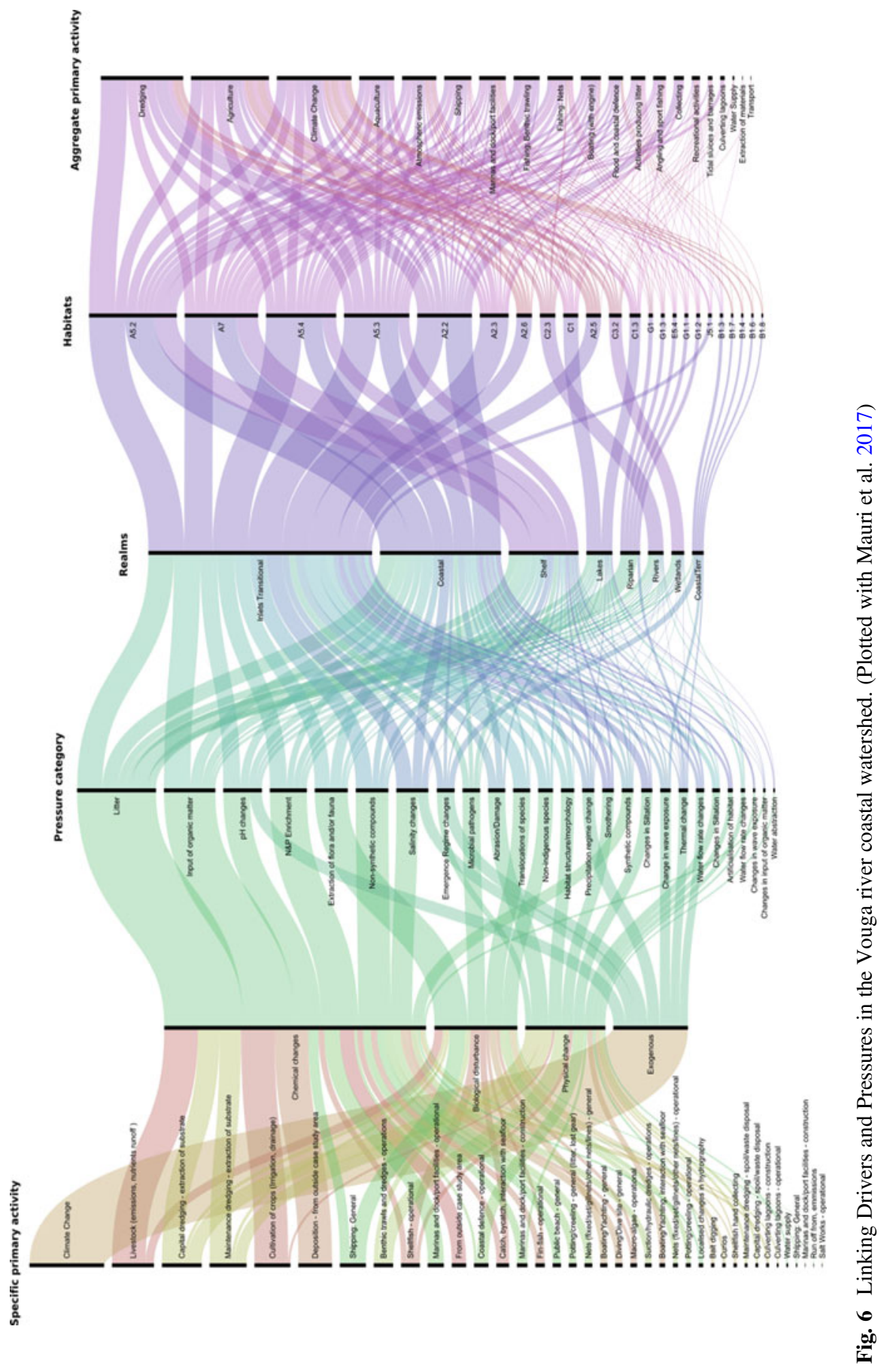



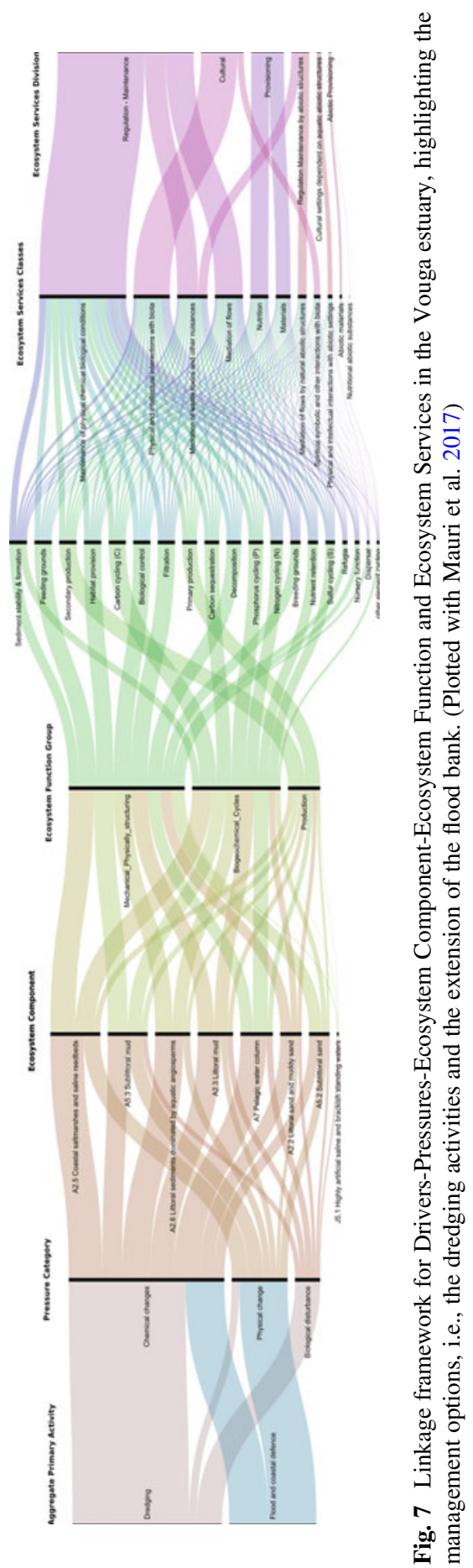
Table 5 Description of proposed EBM responses supported by the prospective scenarios and considering the existing Sectoral Plan for Natura 2000 Network as well as the National Strategic Plan for climate change adaptation

\begin{tabular}{|c|c|c|}
\hline & Seagrasses meadows restoration & Saltmarshes restoration \\
\hline $\begin{array}{l}\text { Main cause for mitiga- } \\
\text { tion measures }\end{array}$ & $\begin{array}{l}\text { Compensate the loss due to } \\
\text { changes in water current velocity } \\
\text { and light availability. }\end{array}$ & $\begin{array}{l}\text { Compensate the loss due to } \\
\text { 'coastal squeeze' and the increase } \\
\text { in tidal prism. }\end{array}$ \\
\hline $\begin{array}{l}\text { Ongoing science based } \\
\text { knowledge to support } \\
\text { mitigation measures }\end{array}$ & $\begin{array}{l}\text { Intertidal Zostera noltei numerical } \\
\text { modelling in Ria de Aveiro (e.g., } \\
\text { Azevedo et al. 2013, 2017). } \\
\text { Research projects BioPradaRia } \\
\text { and Remoliço (PT MAR2020 } \\
\text { funded) testing restoration tech- } \\
\text { niques for Z. noltei populations } \\
\text { in situ and under controlled labo- } \\
\text { ratory conditions. }\end{array}$ & $\begin{array}{l}\text { Running InVEST GIS-based } \\
\text { modelling tool to support the } \\
\text { selection of potential areas, as } \\
\text { well as the restoration techniques. } \\
\text { These might combine nature- } \\
\text { based solutions to protect shore- } \\
\text { lines and actions to promote sed- } \\
\text { iment accretion for salt marsh } \\
\text { elevation. }\end{array}$ \\
\hline $\begin{array}{l}\text { Detailed restoration } \\
\text { measures }\end{array}$ & $\begin{array}{l}\text { (1) Protection of existing } \\
\text { populations from fragmentation } \\
\text { and increase resilience by } \\
\text { enhancing sediment stability } \\
\text { through application of coconuts } \\
\text { fibber mats (e.g., Sousa et al. } \\
\text { 2017a) } \\
\text { (2) Transplantation of } Z \text {. noltei } \\
\text { plots from selected donor sites } \\
\text { within Ria de Aveiro (e.g., } \\
\text { Suykerbuyk et al. 2016) }\end{array}$ & $\begin{array}{l}\text { (1) Restoration of salt-marsh } \\
\text { communities (Sousa et al., } \\
\text { 2017b), namely Juncus } \\
\text { maritimus, through revegetation } \\
\text { of sheltered mudflats, considering } \\
\text { submersion time. (2) Foster } \\
\text { saltmarshes elevation through } \\
\text { accretion. }\end{array}$ \\
\hline
\end{tabular}

Data source: Lillebø et al. (2019)

and secondary) as well as regulation and maintenance, cultural and provisioning ecosystem services and abiotic outputs.

Although dredging activities and extension of the flood bank are acknowledged as important for shipping and agriculture, concerns remain on the impact of dredging on seagrasses, saltmarshes and juvenile fauna due to changes in the ecosystem eco-hydrology.

Overall, stakeholders' sectoral activities (including public and private sectors), or spheres of interest (including direct and indirect users), generate conflicting interests that need to be considered in the context of co-creation of adaptive management solutions that consider better coordination among policies.

The specific policy plans and programmes aiming at mitigating negative unintended impacts on biodiversity in the Natura 2000 Vouga estuary will focus on restoration of tidal wetlands, namely seagrasses and saltmarshes (Table 5), development of the Vouga Estuary Management Plan, engagement of local users and landowners in restoration actions, and the promotion of the value of ecosystems services provided by tidal wetlands. Both measures, to compensate for the loss of seagrasses and saltmarshes, have as policy target the Water Frame Work Directive and the Birds and Habitats Directives. As well, the target policy instruments already in place are River Basin Management Plan and National Water Plan. 


\subsection{Evaluate the EBM Solutions}

The EBM plan, co-created with stakeholders, is shown in Table 6. During the evaluation processes, special attention was given to seagrasses and saltmarshes restoration measures. These measures aim at recovering the ecological processes and services of these valuable coastal wetlands, being in this way ecologically sustainable, socially desirable, ethically defensible, and culturally inclusive.

Table 6 EBM plan alignment with EBM principles

\begin{tabular}{l} 
EBM principles \\
\hline 1. EBM considers ecological integrity, biodi- \\
versity, resilience and ecosystem services
\end{tabular}

EBM scenario

The harmonised WFD and HD monitoring programmes will together with the proposed tidal wetlands restoration measures, and stakeholder participation, increase resilience and ecosystem services.

2. EBM is carried out at appropriate spatial scales

The EBM Plan considers the boundaries of the Vouga Estuary Management Plan and the interconnections with the Ria de Aveiro watershed.

3. EBM develops and uses multi-disciplinary knowledge

The Vouga Estuary Management Plan foresees the coordination between various territorial management instruments as well as stakeholders' sectoral activities, with support of science-based knowledge. The Vouga Estuary Management Plan should therefore involve complementary expertise between and within natural and social sciences, in a transdisciplinary approach.

4. EBM builds on social-ecological interactions, stakeholder participation and transparency
The EBM plan was co-created with input from local stakeholders and policy-makers, and considers their perceptions, namely their concerns regarding the unintended pressures from the base-line scenario, their valuation of ecosystem services through spatial multi-criteria analysis and their recommendations regarding opportunities and constraints regarding implementation of the plan.

5. EBM supports policy coordination

6. EBM incorporates adaptive management
The proposed EBM approach is timely to the Portuguese spatial planning and water planning systems, framed for the protection and management of estuarine systems. The EBM plan also proposes to harmonise Water Framework Directive and Habitats Directive monitoring programmes.

The proposed measures, namely the habitats restoration measures, follow principles of resilience thinking and adaptive management, by considering ecology, management of natural capital and systems analysis.

Source: Lillebø et al. (2019) 
Additionally, the relevance of these coastal wetlands as nursery areas, which support important economic activities in the region, is acknowledged by local populations (Dolbeth et al. 2016; Newton et al. 2018; Lillebø et al. 2019).

For the implementation, relevant EU funding instruments might be considered, namely R\&I H2020 and the following Horizon Europe programmes, LIFE environmental programme, as well as Regional Development and/or Territorial Cooperation funds (Marino et al. 2014; UE 2016).

Both measures to restore tidal wetlands have the same policy target (i.e., Water Framework, Birds and Habitats Directives), are legally permissible, and are implementable using the same policy instrument (River Basin Management Plan; National Water Plan), therefore administratively achievable although it implies the commitment of several Institutions. This is foreseen with the proposed development of the Vouga Estuary Management Plan and is also effectively communicable and politically expedient for promoting the value of ecosystems services provided by tidal wetlands. In addition, effective implementation of proposed habitat restoration in the selected Natura 2000 area is consistent with the prevailing political climate and has explicit support of national political leaders. The main differences between the baseline and the proposed EBM solutions are shown in Table 7.

The performance of the proposed EBM measures is presented in Table 8. The baseline scenario corresponds to the unintended impacts on biodiversity, i.e., increase in tidal prism and water velocity; loss of coastal wetlands habitats (seagrasses and saltmarshes) and saltmarsh 'coastal squeeze' at the downstream area of the flood bank.

\section{Vouga Estuary Natura 2000 Site Stakeholders' Evaluation and Feedback}

Local stakeholders were supportive of the approach, "ecosystem-based management allows for a 'correction' of less good results" and appreciate that it is "concerned with beneficiaries, as well as biodiversity". Overall, stakeholders considered that:

- The environment and biodiversity will be the main beneficiaries from tidal wetlands restoration;

- Some economic activities related to fisheries and ecotourism, which has a recognized potential, might benefit;

- Restoration actions need to ensure involvement of users due to conflicting activities and landowners, as most of the area is private property;

- Large interventions should include financing for implementation of the corresponding minimizing measures;

- There is a need for post-licensing supervision to ensure compliance with environmental protection obligations;

- There is a need for clear communication between institutions and enforcement of existing regulations; 
Table 7 Main differences between the baseline and proposed EBM solutions

\begin{tabular}{l|l|l}
\hline $\begin{array}{l}\text { Main } \\
\text { differences }\end{array}$ & Baseline & EBM solutions \\
\hline $\begin{array}{l}\text { Environmental } \\
\text { ambition/pol- } \\
\text { icy target }\end{array}$ & $\begin{array}{l}\text { Protect biodiversity in line with Natura } \\
\begin{array}{l}\text { 2000 objectives. Whilst enabling eco- } \\
\text { nomic and other activities in the area, } \\
\text { aim to mitigate negative impacts of } \\
\text { interventions and economic activity. }\end{array}\end{array}$ & Same as in baseline. \\
\hline Measures & $\begin{array}{l}\text { Two measures are to be implemented } \\
\text { in 2019/2020, which will have fore- } \\
\text { seen but unintended negatives impacts } \\
\text { on biodiversity (dredging programme } \\
\text { and the extension of a flood bank). }\end{array}$ & $\begin{array}{l}\text { The same as baseline, but to minimise } \\
\text { negative side effects, additional mea- } \\
\text { sures are proposed (see Table 5). }\end{array}$ \\
\hline $\begin{array}{l}\text { Policy } \\
\text { instruments }\end{array}$ & $\begin{array}{l}\text { Many policy instruments are } \\
\text { implemented to achieve biodiversity } \\
\text { goals, including protected areas. }\end{array}$ & $\begin{array}{l}\text { Harmonise monitoring across water } \\
\text { and environmental related Directives; } \\
\text { Incorporate stakeholders into plan- } \\
\text { ning; Integrate territorial manage- } \\
\text { ment institutions (and their multiple } \\
\text { goals) into planning; Support devel- } \\
\text { opment of Vouga Estuary } \\
\text { Management Plan. }\end{array}$ \\
\hline Sites & $\begin{array}{l}\text { The boundaries of the Vouga Estuary } \\
\text { Management Plan and the inter- } \\
\text { connections with the Ria de Aveiro } \\
\text { watershed. }\end{array}$ & $\begin{array}{l}\text { Same as in baseline; } \\
\text { Seagrass and saltmarsh restoration } \\
\text { sites will be selected considering } \\
\text { multiple ecosystem services and with } \\
\text { stakeholder input. }\end{array}$ \\
\hline $\begin{array}{l}\text { Governance/ } \\
\text { contitutional }\end{array}$ & $\begin{array}{l}\text { Many separate; Limited, inconsistent } \\
\text { stakeholder involvement in } \\
\text { management. }\end{array}$ & $\begin{array}{l}\text { Coordinated input from multiple } \\
\text { institutions into integrated Vouga } \\
\text { Estuary Management Plan. } \\
\text { Ongoing, coordinated stakeholder } \\
\text { engagement in management. }\end{array}$ \\
\hline
\end{tabular}

Source: Mattheiß et al. (2018)

- There is a need for reinforcement of integrated management and development the Vouga Estuary Management Plan.

As part of the co-creation process, stakeholders evaluated the produced maps, the ecosystem indicators' results, the proposed EBM solutions, and they discussed the benefits and constraints regarding its implementation. As a final remark stakeholders acknowledged that responses should be framed in the Sectoral Plan for Natura 2000 Network, and should consider climate change projections and the National Strategic Plan for climate change adaptation (Fig. 8 illustrates the spatial planning regulations to consider for climate change adaptation in the region).

At the Vouga river coastal watershed the Sectoral Plan for Natura 2000 Network establishes the strategic orientation and programme norms for the actions of central and local government, and the measures and guidelines provided therein should be transposed to the Municipal Planning of the territory and Special Plans. Thus, the management measures provided for the Sectoral Plan will only be binding measures when they are inserted in the Municipal and Special Plans. Within the considered 
Table 8 Application of the pre-screening criteria: effectiveness, efficiency, and equity and fairness

\begin{tabular}{l|l}
\hline Pre-screening criteria & EBM solutions \\
\hline $\begin{array}{l}\text { Effectiveness-hitting the envi- } \\
\text { ronmental target }\end{array}$ & $\begin{array}{l}\text { The proposed measures, i.e., saltmarshes restoration and } \\
\text { seagrasses restoration clearly address the set of environmental } \\
\text { targets defined under relevant policies. }\end{array}$ \\
\hline $\begin{array}{l}\text { Efficiency_making the most for } \\
\text { human wellbeing }\end{array}$ & $\begin{array}{l}\text { Although proposed measures were not supported by cost- } \\
\text { effectiveness analysis or cost-benefit-analysis, they were } \\
\text { supported by a spatial multi-criteria analysis performed by } \\
\text { stakeholders in which they expressed preferences regarding } \\
\text { the provided ecosystem services. }\end{array}$ \\
\hline $\begin{array}{l}\text { Equity and fairness_-sharing } \\
\text { the benefits }\end{array}$ & $\begin{array}{l}\text { By integrating the proposed measures in the Vouga Estuary } \\
\text { Management Plan, and by acknowledging the context of } \\
\text { adaptation to climate change, strategy for Biodiversity and the } \\
\text { Centro Portugal region strategy for smart specialisation (Por- } \\
\text { tugal RIS3 Centro), stakeholders with very different interests } \\
\text { participated actively and acknowledge the equity of benefits } \\
\text { already achieved, or to be achieved, although they identified } \\
\text { constraints regarding its implementation. }\end{array}$ \\
\hline
\end{tabular}

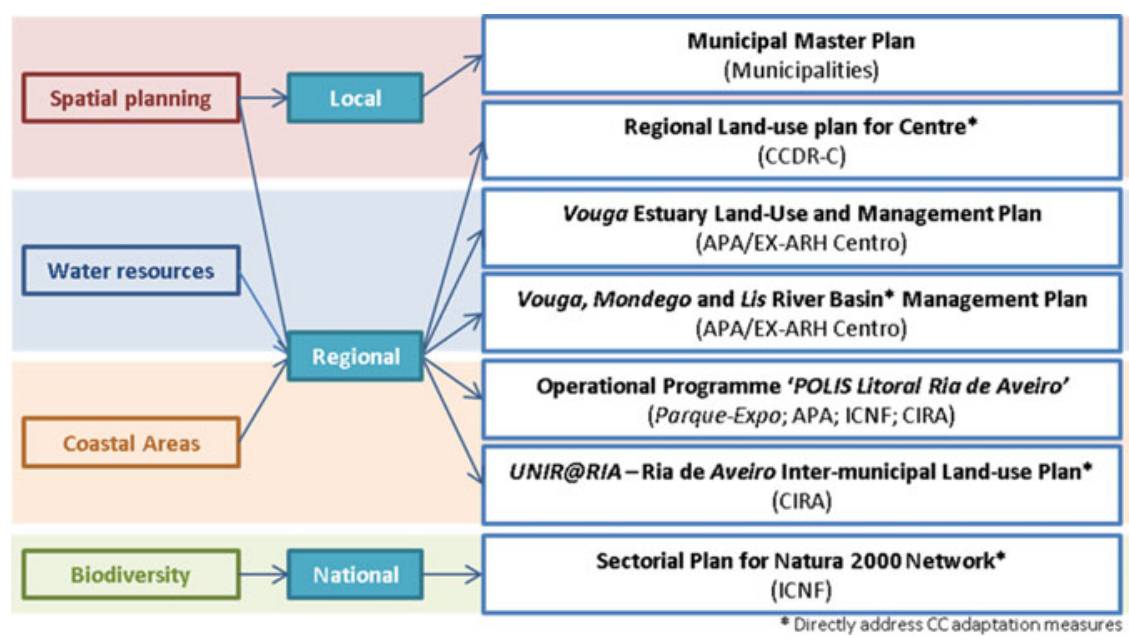

Fig. 8 Spatial planning regulations for climate change adaptation for Vouga river coastal watershed. (Source: ADAPT-MED 2015)

boundaries, this plan is implemented by the UNIR@RIA, which ensures articulation between the regional and municipal plans that are relevant for the Ria de Aveiro and associated protected areas.

The National Strategic Plan for climate change adaptation is framed on a Territorial Management System organized within a framework of coordinated interaction at three levels (Law no. 48/98, August 11): national, regional and local.

Acknowledgements The European Commission under the Horizon 2020 Programme for Research, Technological Development and Demonstration supported this study through the 
collaborative research project AQUACROSS (Grant Agreement no. 642317). Thanks, are also due to the Portuguese Foundation for Science and Technology (FCT) for the financial support to CESAM (UID/AMB/50017/2019; UIDP/50017/2020+UIDB/50017/2020). Ana Genua-Olmedo was funded by the project PORBIOTA-Portuguese E-Infrastructure for Information and Research on Biodiversity (POCI-01-0145-FEDER-022127), financed by FCT through PIDAC national funds and co-funded by the FEDER. Special thanks to Mariana Morgado for her work in the cartographic data collection, and to stakeholders participating at the workshops for their valuable contribution.

\section{References}

ADAPT-MED. (2015). Baixo Vouga Lagunar Knowledge Database. ADAPT-MED Report D2.1b. $92 \mathrm{pp}$.

APA. (2018). RECAPE da Transposição de Sedimentos para Otimização do Equilíbrio Hidrodinâmico na Ria de Aveiro - Canal de Ovar até ao Carregal, Canal de Ovar até ao Pardilhó e Canal da Murtosa Canal de Ílhavo, Canais do Lago Paraíso e Canais da Zona Central da Ria 35.

Azevedo, A., Sousa, A. I., Lencart e Silva, J. D., Dias, J. M., \& Lillebø, A. I. (2013). Application of the generic DPSIR framework to seagrass communities of Ria de Aveiro: A better understanding of this coastal lagoon. Journal of Coastal Research, 65, 19-24.

Azevedo, A., Lillebø, A. I., Silva, J. L. E., \& Dias, J. M. (2017). Intertidal seagrass models: Insights towards the development and implementation of a desiccation module. Ecological Modelling, $354,20-25$.

Curtin, C. G., \& Parker, J. P. (2014). Foundations of resilience thinking. Conservation Biology, 28, 912-923.

Direção Regional de Agricultura e Desenvolvimento Rural. (2017). Aproveitamento Hidroagrić ola do Vouga Bloco do Baixo Vouga Lagunar. Intervenções nos Sistemas Primários de Drenagem e Defesa Contra Efeitos das Marés e Cheias a Candidatar à Operação 3.4.3 do PDR 2020.

Dolbeth, M., Stalnacke, P., Alves, F. L., Sousa, L. P., Gooch, G. D., Khokhlov, V., Tuchkovenko, Y., Lloret, J., Bielecka, M., Rozynski, G., Soares, J. A., Baggett, S., Margonski, P., Chubarenko, B. V., \& Lillebø, A. I. (2016). An integrated Pan-European perspective on coastal lagoons management through a mosaic-DPSIR approach. Scientific Reports, 6, 19400.

Drakou, E. G., Kermagoret, C., Liquete, C., Ruiz-Frau, A., Burkhard, K., Lillebø, A. I., van Oudenhoven, A. P. E., Ballé-Béganton, J., Rodrigues, J. G., Nieminen, E., Oinonen, S., Ziemba, A., Gissi, E., Depellegrin, D., Veidemane, K., Ruskule, A., Delangue, J., Böhnke-Henrichs, A., Boon, A., Wenning, R., Martino, S., Hasler, B., Termansen, M., Rockel, M., Hummel, H., El Serafy, G., \& Peev, P. (2017). Marine and coastal ecosystem services on the science-policypractice nexus: Challenges and opportunities from 11 European case studies. International Journal of Biodiversity Science, Ecosystem Services \& Management, 13(3), 51-67.

European Commission. (2011). Our life insurance, our natural capital: An EU biodiversity strategy to 2020. Brussels: European Commission.

Fidélis, T., \& Carvalho, T. (2015). Estuary planning and management: The case of Vouga Estuary (Ria de Aveiro), Portugal. Journal of Environmental Planning and Management, 58(7), 1173-1195.

Fidélis, T., Teles, F., Roebeling, P., \& Riazi, F. (2019). Governance for sustainability of estuarine areas-assessing alternative models using the case of Ria de Aveiro. Portugal Water, 2019(11), 846.

Gómez, C., Delacámara, G., Arévalo-torres, J., Barbière, J., Barbosa, A. L., Boteler, B., Culhane, F., Daam, M., Gosselin, M.-P., Hein, T., Iglesias-campos, A., Jähnig, S., Lago, M., Langhans, S., Martínez-López, J., Nogueira, A., Lillebø, A. I., O’Higgins, T., Piet, G., \& Schlüter, M. (2016). The AQUACROSS innovative concept-deliverable 3.1. 
Gómez, C., Delacámara, G., Jähnig, S., Langhans, S. D., Domisch, S., Hermoso, V., Piet, G., Martínez-López, J. B., Lago, M., Boteler, B., Rouillard, J., Abhold, K., Reichert, P., Schuwirth, N., Hein, T., Pletterbauer, F., Funk, A., Nogueira, A., Lillebø, A. I., Daam, M., Teixeira, H., Robinson, L., Culhane, F., Schlüter, M., Martin, R., Iglesias-Campos, A., Luisa Barbosa, A., \& Arévalo-Torres, J. (2017). Developing the AQUACROSS assessment framework deliverable 3.2.

Haines-Young, R., \& Potschin, M. B. (2017). Common international classification of ecosystem services (CICES) V5.1 and guidance on the application of the revised structure. Retrieved from www.cices.eu.

Langhans, S. D., Domisch, S., Balbi, S., Delacámara, G., Hermoso, V., Kuemmerlen, M., Martin, R., Martínez-López, J., Vermeiren, P., Villa, F., \& Jähnig, S. C. (2019). Combining eight research areas to foster the uptake of ecosystem-based management in fresh waters. Aquatic Conservation: Marine and Freshwater Ecosystems, 29(2), 1161-1173. https://doi.org/10.1002/ aqc. 3012 .

Lilleb $\varnothing$, A. I., Stålnacke, P., \& Gooch, G. D. (Eds.). (2015). Coastal lagoons in Europe: Integrated water resource strategies. IWA Publishing; International Water Association (IWA), UK, 254pp. ISBN: 9781780406282; eISBN: 9781780406299. Retrieved from https://www. iwapublishing.com/sites/default/files/ebooks/9781780406299.full_.pdf.

Lillebø, A. I., Stålnacke, P., Gooc, G. D., Krysanova, V., \& Bielecka, M. (2016). Pan-European management of coastal lagoons: A science-policy-stakeholder interface perspective. Coastal and Shelf Science: Estuarine.

Lillebø, A. I., Teixeira, H., Nogueira, A. J. A., Genua-Olmedo, A., Morgado, M., \& Ferreira, V. (2018). AQUACROSS. 2018. Implementando uma gestão baseada nos ecossistemas aquáticos da Rede Natura 2000 da Ria de Aveiro: da Pateira até ao mar, passando pelo Baixo Vouga Lagunar (A. I. Lillebø, H. Teixeira, \& A. J. A. Nogueira, Eds., 60 pp). ISBN: 978-98999524-2-3.

Lillebø, A. I., Teixeira, H., Morgado, M., Martínez-López, J., Marhubi, A., Delacamara, G., Strosser, P., \& Nogueira, A. J. A. (2019). Ecosystem-based management planning across aquatic realms at the Ria de Aveiro Natura 2000 territory. Science of the Total Environment, $650,1898-1912$.

Lopes, J. F., Ferreira, J. A., Cardoso, A. C., \& Rocha, A. C. (2014). Variability of temperature and chlorophyll of the Iberian Peninsula near costal ecosystem during an upwelling event for the present climate and a future climate scenario. Journal of Marine Systems, 129, 271-288.

Lopes, M. L., Marques, B., Dias, J. M., Soares, A. M. V. M., \& Lillebø, A. I. (2017). Challenges for the WFD second management cycle after the implementation of a regional multi-municipality sanitation system in a coastal lagoon (Ria de Aveiro, Portugal). Science of the Total Environment, 586, 215-225.

Luís, S., Lima, M. L., Roseta-Palma, C., Rodrigues, N., Sousa, L. P., Freitas, F., Alves, F. L., Lillebø, A. I., Parrod, C., Jolivet, V., Paramana, T., Alexandrakis, G., \& Poulos, S. (2018). Psychosocial drivers for change: Understanding and promoting stakeholder engagement in local adaptation to climate change in three European Mediterranean case studies. Journal of Environmental Management, 223, 165-174.

Maes, J., Liquete, C., Teller, A., Erhard, M., Paracchini, M. L., Barredo, J. I., Grizzetti, B., Cardoso, A., et al. (2016). An indicator framework for assessing ecosystem services in support of the EU biodiversity strategy to 2020. Ecosystem Services, 17, 14-23.

Martin, R., Hellquist, F. K., Schlüter, M., Barbosa, A. L., Iglesias-Campos, A., Torres, J. A., Barbière, J., Martin, B., Delacámara, G., Gómez, C. M., Arenas, M., Domisch, S., Langhans, S., Martínez-López, J., Villa, F., Balbi, S., Schuwirth, N., \& Rouillard, J. (2018). Scenario development. Deliverable 7.2, European Union's Horizon 2020 Framework Programme for Research and Innovation Grant Agreement No. 642317. 52 pp. [Online]. Retrieved from https:// aquacross.eu. 
Martínez-López, J., Bergillos, R. J., Bonet-García, F., \& de Vente, J. (2019a). Connecting research infrastructures, scientific and sectorial networks to support integrated management of Mediterranean coastal and rural areas. Environmental Research Letters. https://doi.org/10.1088/17489326/ab4b22.

Martínez-López, J., Teixeira, H., Morgado, M., Almagro, M., Sousa, A. I., Villa, F., Balbi, S., Genua-Olmedo, A., Nogueira, A. J. A., \& Lilleb $\varnothing$, A. I. (2019b). Participatory coastal management through elicitation of ecosystem service preferences and modelling driven by "coastal squeeze”. Science of the Total Environment, 652, 1113-1128.

Mattheiß, V., Strosser, P., Krautkraemer, A., Charbonnier, C., McDonald, H., Röschel, L., Hoffmann, H., Lago, M., Delacámara, G., Gómez, C.M., Piet, G., Schuwirth, N., Kuemmerlen, M., \& Reichert, P. (2018). Evaluation of ecosystem-based management responses in case studies: AQUACROSS deliverable 8.2. European Union's Horizon 2020 Framework Programme For Research and Innovation Grant Agreement No. 642317.

Mauri, M., Elli, T., Caviglia, G., Uboldi, G., \& Azzi, M., (2017). RAWGraphs: A visualisation platform to create open outputs. Proceedings of the 12th Biannual Conference on Italian SIGCHI Chapter. ACM, p. 28.

Marino, D., Gaglioppa, P., Schirpke, U., Guadagno, R., Marucci, A., Palmieri, M., Pellegrino, D., \& Gusmerotti, N. (2014). Assessment and governance of ecosystem services for improving management effectiveness of natura 2000 sites. Bio-based Applied Economics, 3, 229-247.

Newton, A., Brito, A. C., Icely, J. D., Derolez, V., Clara, I., Angus, S., Schernewski, G., Inácio, M., Lillebø, A. I., \& Sousa, A. I. (2018). Assessing, quantifying and valuing the ecosystem services of coastal lagoons. Journal for Nature Conservation, 44, 50-65.

O’Higgins, T., Nogueira, A. J. A., \& Lillebø, A. I. (2019). A simple spatial typology for assessment of complex coastal ecosystem services across multiple scales. Science of the Total Environment, $649,1452-1466$.

Pereira, C., \& Coelho, C. (2013). Mapping erosion risk under different scenarios of climate change for Aveiro coast, Portugal. Natural Hazards, 69, 1033-1050.

Piet, G., Delacámara, G., Gómez, C.M., Lago, M., Rouillard, J., Martin, R., \& van Duinen, R. (2017). Making ecosystem-based management operational. Deliverable 8.1, European Union's Horizon 2020 Framework Programme for Research and Innovation Grant Agreement No. 642317. 49 pp. [Online]. Retrieved from https://aquacross.eu.

Rouillard, J., Lago, M., Abhold, K., Röschel, L., Kafyeke, T., Mattheiß, V., \& Klimmek, H. (2018). Protecting aquatic biodiversity in Europe: How much do EU environmental policies support ecosystem-based management? Ambio, 47, 15-24.

Sousa, L. P. (2017). Integration of ecosystem services and its value in an estuary governance model in the context of climate change: Application to Ria de Aveiro Coastal Lagoon. $\mathrm{PhD}$ Thesis, University of Aveiro.

Sousa, L. P., Sousa, A. I., Alves, F. L., \& Lilleb $\varnothing$, A. I. (2016). Ecosystem services provided by a complex coastal region: Challenges of classification and mapping. Scientific Reports, 6, 22782.

Sousa, A. I., Valdemarsen, T., Lilleb $\varnothing$, I., Jorgensen, L., \& Flindt, M. R. (2017a). A new marine measure enhancing Zostera marina seed germination and seedling survival. Ecological Engineering, 104, 131-140.

Sousa, A. I., Santos, D. B., Ferreira da Silva, E., Sousa, L. P., Cleary, D. F. R., Soares, A. M. V. M., $\&$ Lillebø, A. I. (2017b). 'Blue carbon' and nutrient stocks of salt marshes at a temperate coastal lagoon (Ria De Aveiro, Portugal). Scientific Reports, 7, 41225.

Stefanova, A., Krysanova, V., Hesse, C., \& Lilleb $\varnothing$, A. I. (2015). Climate change impact assessment on water inflow to a coastal lagoon - Ria de Aveiro watershed, Portugal. Hydrological Sciences Journal-Journal des Sciences Hydrologiques (Special Issue: Evaluation of Water Resources with SWAT, 60(5), 929-948.

Suykerbuyk, W., Govers, L. L., Bouma, T. J., Giesen, W. B., de Jong, D. J., van de Voort, R., Giesen, K., Giesen, P. T., \& van Katwijk, M. M. (2016). Unpredictability in seagrass restoration: Analysing the role of positive feedback and environmental stress on Zostera noltii transplants. Journal of Applied Ecology, 53(3), 774-784. 
Teixeira, H., Lillebø, A., Culhane, F., Robinson, L., Trauner, D., Borgwardt, F., Kummerlen, M., Barbosa A., McDonald, H., Funk, A., O’Higgins, T., Van der Wal, T., Piet, G., Hein, T., Arévalo-Torres, J., Barbière, J., \& Nogueira, A. J. A. (2018). Assessment of causalities, highlighting results from the application of meta-ecosystem analysis in the case studies Synthesis report. Deliverable 5.2, European Union's Horizon 2020 Framework Programme for Research and Innovation Grant Agreement No. 642317. [Online]. Retrieved from https:// aquacross.eu.

Teixeira, H., Lillebø, A. I., Culhane, F., Robinson, L., Trauner, D., Borgwardt, B., Kummerlen, M., Barbosa, A., McDonald, H., Funk, A., O’Higgins, T., Van der Wal, J. T., Piet, G., Hein, T., Arévalo-Torres, J., Iglesias-Campos, A., Barbière, J., \& Nogueira, A. J. A. (2019). Flow linkages from biodiversity to ecosystem services supply: Integrating across aquatic ecosystems. Science of the Total Environment, 657, 517-534.

Teles, F., Fidélis, T., Roebeling, P., Lillebø, A. I., \& Lucas Pires, M. A. (2014). Ria de Aveiro Governance. Policy Paper prepared for the Intermunicipal Community of the Ria de Aveiro; University of Aveiro.

Villa, F., Tunesi, L., \& Agardy, T. (2002). Zoning marine protected areas through spatial multiplecriteria analysis: The case of the Asinara Island National Marine Reserve of Italy. Conservation Biology, 16(2), 515-526.

Open Access This chapter is licensed under the terms of the Creative Commons Attribution 4.0 International License (http://creativecommons.org/licenses/by/4.0/), which permits use, sharing, adaptation, distribution and reproduction in any medium or format, as long as you give appropriate credit to the original author(s) and the source, provide a link to the Creative Commons licence and indicate if changes were made.

The images or other third party material in this chapter are included in the chapter's Creative Commons licence, unless indicated otherwise in a credit line to the material. If material is not included in the chapter's Creative Commons licence and your intended use is not permitted by statutory regulation or exceeds the permitted use, you will need to obtain permission directly from the copyright holder. 